\title{
Article \\ Effects of Fluorogypsum and Flue-Gas Desulfurization Gypsum on the Hydration and Hardened Properties of Alkali Slag Cement
}

\author{
Cheng Wang ${ }^{1}{ }^{(}$, Hang $\mathrm{He}^{2, *}$, Yuli Wang ${ }^{2} \mathbb{D}$ and Wenyue Xue ${ }^{1}$ \\ 1 Collaborative Innovation Center of Coal Work Safety of Henan Province, School of Energy Science and \\ Engineering, Henan Polytechnic University, Jiaozuo 454003, China; wangcheng@hpu.edu.cn (C.W.); \\ xuewenyue2021@163.com (W.X.) \\ 2 Key Laboratory for Deep-Earth Materials Science and Technology of Henan Province, College of Materials \\ Science and Engineering, Henan Polytechnic University, Jiaozuo 454003, China; wangyuli@hpu.edu.cn \\ * Correspondence: 211606020018@home.hpu.edu.cn; Tel.: +86-1827-2732-988
}

check for updates

Citation: Wang, C.; He, H.; Wang, Y.; Xue, W. Effects of Fluorogypsum and Flue-Gas Desulfurization Gypsum on the Hydration and Hardened Properties of Alkali Slag Cement. Crystals 2021, 11, 1475. https:// doi.org/10.3390/cryst11121475

Academic Editors: Linda Pastero,

Yi Bao, Salman Siddique,

Wei-Ting Lin and Trilok Gupta

Received: 29 October 2021

Accepted: 24 November 2021

Published: 27 November 2021

Publisher's Note: MDPI stays neutral with regard to jurisdictional claims in published maps and institutional affiliations.

Copyright: (c) 2021 by the authors. Licensee MDPI, Basel, Switzerland. This article is an open access article distributed under the terms and conditions of the Creative Commons Attribution (CC BY) license (https:// creativecommons.org/licenses/by/ $4.0 /)$.

\begin{abstract}
In order to explore the influence of the types of waste gypsum on the properties of alkali slag cement, fluorogypsum (FG) and flue-gas desulfurization (FGD) gypsum were comparatively investigated. Moreover, the action mechanisms of FG and FGD gypsum on the properties of alkali slag cement were analyzed. The results show that both the FG and FGD gypsum prolonged the setting time of the alkali slag cement paste. However, the prolongation effect of FG was more pronounced than the FGD gypsum. When the compressive strength was maximum, the contents of FG and FGD gypsum were 5 and 6 wt.\%, respectively. At 3 and 28 days, compared to the control sample, the compressive strengths increased by $59.3 \%$ and $24.3 \%$, and $66.9 \%$ and $33.9 \%$, respectively. Furthermore, the XRD, TG-DTA and SEM-EDS results showed that, with the increase in the contents of FG and FGD gypsum, ettringite was more easily produced and the hydration products were more abundant in the system. The greater the gypsum content of the paste, the less accumulated was the heat of hydration. The change of micro-structure caused by the formation of ettringite was the main reason for the difference in the properties of cement.
\end{abstract}

Keywords: fluorogypsum; flue-gas desulfurization (FGD) gypsum; alkali slag cement; compressive strength; micro-structure

\section{Introduction}

During the production of Portland cement, a large amount of carbon dioxide is produced, which leads to the greenhouse effect [1,2]. In recent years, in order to reduce the environmental concerns arising from the preparation of clinkers for Portland cement, the search for new cementitious materials requiring low or no clinker has become a research focus. As a solid waste, slag is potentially reactive due to its high silica and alumina contents and can be used as a component of cementitious material. Therefore, the application prospects of alkali slag cement, which uses the reactivity of slag with alkaline activators to prepare hydraulic cementitious materials, are becoming increasingly promising [3,4]. Fluorogypsum (FG) is a by-product of the production of hydrofluoric acid and mainly consists of anhydrite. Flue-gas desulfurization (FGD) gypsum is the waste produced during the flue-gas desulfurization process in thermal power plants. Both of them have the characteristics of large output, high purity, and difficulty in being reused. Both the byproducts are a waste of resources and result in environmental pollution.

Many studies have been carried out to make better use of FG and FGD gypsum. Compared with various admixtures such as silica fume, fly ash and metakaolin, when FG is compounded with Portland cement, the hydration reaction of the cementitious material is sufficient at the early age, and results in changes to the morphology of gypsum and 
a more compact structure of the hydration products $[5,6]$. Compared with the singlecomponent cement, when FG is mixed, the exothermic peak of the paste appears earlier, which promotes the hydration of the cement [7]. Garg et al. [8] found that the hydration products (mainly $\mathrm{C}-\mathrm{S}-\mathrm{H}$ gel and ettringite) were also aggregated around the gypsum and filled in the pores, thus reducing the porosity of the hardened pastes and improving the strength and water resistance. The study of Magallanes et al. [9] reached a similar conclusion. Moreover, FG can greatly reduce the amount of Portland cement, whereas the strength and the stability of the volume of the hardened pastes does not deteriorate [10-12]. Huang et al. [13] used FG to prepare a new type of cementitious material that rendered the mortar good late-stage strength and water resistance and contained only $5 \%$ of Portland cement. FG has also been used to adjust the setting time of the paste; however, its use is currently relatively limited [14]. Yan et al. [15] used modified FG, which significantly delayed the cement hydration and prolonged the setting time of the paste. Moreover, various engineering applications have made use of boards/bricks that were made up of gravel, fiber and FG [16].

Similarly, FGD gypsum has also been studied for use in the field of building materials. Compared with the natural gypsum, FGD gypsum has a poorer particle size distribution, though it possesses a flatter and smoother surface [17]. Moreover, FGD gypsum also has a delaying effect on the setting time of the paste and promotes the formation of ettringite and $\mathrm{C}-\mathrm{S}-\mathrm{H}$ gel and the formation of matrix coating, which result in a more compact mortar or concrete structure, thus increasing the strength and stability of the volume of the mixture [18-21]. In the gypsum-metakaolin-cement system, although the dried FGD gypsum slightly reduced the workability of the mortar, the interval between the initial setting and the final setting was shortened and the mechanical properties after 28 days were better than those of the cement mortar [22]. Duan et al. [23] mixed 10\% FGD gypsum with fly ash-slag-cement system to obtain samples with better strength and water resistance, and reported that more ettringite and $\mathrm{C}-\mathrm{S}-\mathrm{H}$ gels were produced by the system. $\mathrm{Wu}$ et al. [24] pointed out that the addition of $6 \%$ Portland cement clinker with a particle size of $26 \mu \mathrm{m}$ to FGD gypsum increased the flexural strength of the gypsum board by $56 \%$. Zhao et al. [25] used modifiers to prepare waterproof gypsum blocks with the softening coefficient and thermal conductivity values of 0.84 and $0.15 \mathrm{~W} /(\mathrm{m} \cdot \mathrm{K})$, respectively. Some studies focusing on sulfoaluminate cement have shown that a certain amount of FGD gypsum can promote the hydration of cement and accelerate the formation of $\mathrm{Al}(\mathrm{OH})_{3}$ [26]. Ren et al. [27] prepared sulfoaluminate cement clinker with the main minerals of $\mathrm{C}_{4} \mathrm{~A}_{3} \mathrm{~S}$, $\mathrm{C}_{2} \mathrm{~S}$ and $\mathrm{C}_{4} \mathrm{AF}$ by using $25-35 \%$ of FGD gypsum and reported that the 28 -day compressive strength of the clinker reached the value of $75 \mathrm{MPa}$. In order to reduce industrial carbon dioxide emissions using the mineral carbonation reaction, the use of desulfurized gypsum to prepare high-purity calcium carbonate crystals is also being gradually explored [28,29].

In short, the research on both types of gypsums (FG and FGD gypsum) has been relatively more focused on the basis of Portland cement. Some studies [30,31] have shown that both the gypsums (FG and FGD gypsum) have a beneficial effect when used in conjunction with slag. Therefore, if the application of the two types of gypsums and alkali slag cement can be combined, the utilization rate of resources will improve, and novel ways of using these resources could be explored. In this work, the influences of FG and FGD gypsum on the setting time, compressive strength, and micro-structure of the paste were comparatively studied by replacing alkali slag cement with the same mass of gypsum. In addition, the reasons for the difference in macroscopic properties of alkali slag cement with different gypsum contents were also evaluated. In summary, through the study of this paper, a good reference value for the application of waste gypsum in alkali slag cement and a certain guiding significance for the engineering application of waste gypsum in alkali-activated cementitious material system was provided. 


\section{Materials and Methods}

\subsection{Materials}

In the current work, granulated blast-furnace slag (GBFS) was used, which had a density and specific surface area of $2.86 \mathrm{~g} / \mathrm{cm}^{3}$ and $440.7 \mathrm{~m}^{2} / \mathrm{kg}$, respectively. The main chemical composition of the GBFS is presented in Table 1. The FG and FGD gypsum had densities of 2.59 and $2.19 \mathrm{~g} / \mathrm{cm}^{3}$, respectively. The main chemical compositions of the FG and FGD gypsum are presented in Tables 2 and 3, respectively. The main mineral compositions of GBFS, FG and FGD gypsum are shown in Figure 1, and the particle size distributions of FG and FGD gypsum are shown in Figure 2. Moreover, $\mathrm{NaOH}$ was used as the activator and had the effective content of $\geq 96.0 \mathrm{wt} . \%$. Tap water was used throughout the experiments.

Table 1. Main chemical compositions of GBFS/wt.\%.

\begin{tabular}{ccccccccc}
\hline $\mathrm{CaO}$ & $\mathrm{Al}_{2} \mathbf{O}_{3}$ & $\mathrm{SiO}_{2}$ & $\mathrm{Fe}_{2} \mathbf{O}_{3}$ & $\mathbf{M g O}$ & $\mathrm{SO}_{3}$ & $\mathbf{K}_{2} \mathbf{O}$ & $\mathbf{N a}_{2} \mathbf{O}$ & LOI \\
\hline 35.86 & 11.22 & 33.50 & 1.10 & 8.39 & 0.19 & 0.69 & 0.44 & 1.02 \\
\hline
\end{tabular}

Table 2. Main chemical compositions of FG/wt.\%.

\begin{tabular}{ccccccccc}
\hline $\mathrm{CaO}$ & $\mathrm{SO}_{3}$ & $\mathrm{MgO}$ & $\mathrm{Al}_{2} \mathrm{O}_{3}$ & $\mathrm{Fe}_{2} \mathrm{O}_{3}$ & Soluble $\mathrm{F}^{-}$ & $\mathrm{All} \mathrm{F}^{-}$ & Bound Water & LOI \\
\hline 41.20 & 56.10 & 0.14 & 0.05 & 0.17 & 0.05 & 0.52 & 0.83 & 1.0 \\
\hline
\end{tabular}

Table 3. Main chemical compositions of FGDG/wt.\%.

\begin{tabular}{ccccccc}
\hline $\mathrm{CaO}$ & $\mathrm{SO}_{3}$ & $\mathrm{SiO}_{2}$ & $\mathrm{Al}_{2} \mathrm{O}_{3}$ & $\mathrm{MgO}$ & $\mathrm{Fe}_{2} \mathrm{O}_{3}$ & Bound Water \\
\hline 32.34 & 41.12 & 1.60 & 1.07 & 0.14 & 0.21 & 10.59 \\
\hline
\end{tabular}

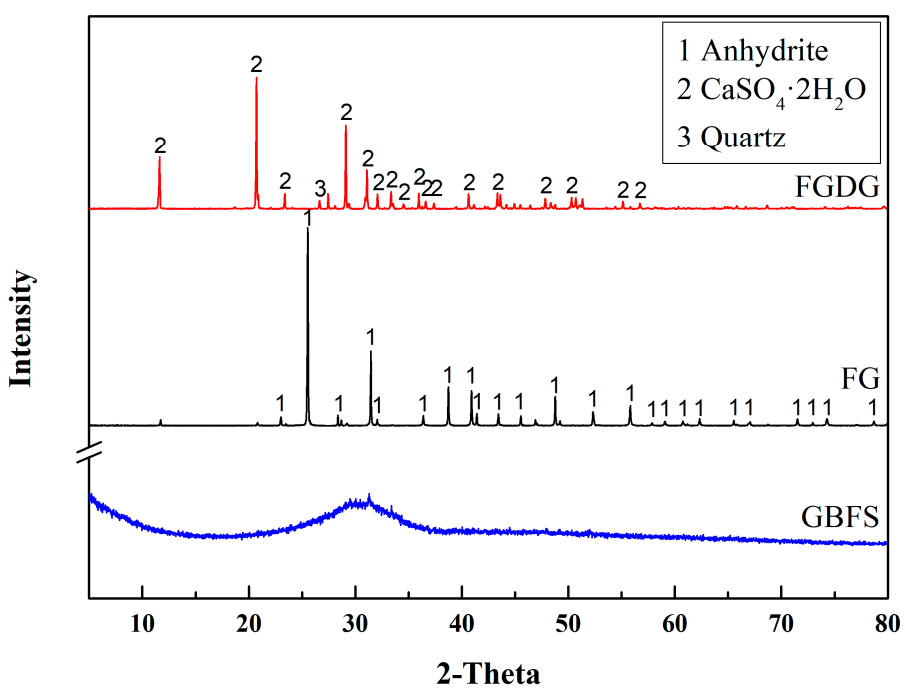

Figure 1. XRD pattern of mineral composition of GBFS, FG and FGDG. 


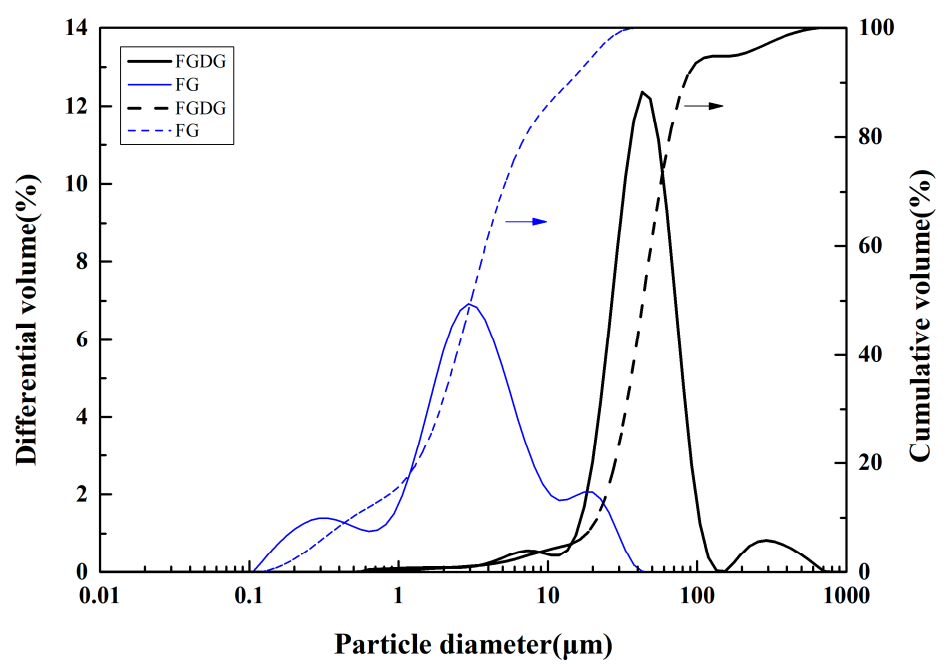

Figure 2. Particle size distribution of FG and FGDG.

\subsection{Test Methods}

Table 4 presents the data regarding the design of the mix (paste). The density of the cement decreased with the increase in the content of both types of gypsum. In contrast to FG, the FGD gypsum had little influence on the density of the paste. The experiments on the setting time were conducted following the national standard China SAOT GB/T-13462011 [32]. The compressive strength was tested at 3, 7 and 28 days for the samples with dimensions of $40 \times 40 \times 40 \mathrm{~mm}$. The dimensions of the samples for the variation in mass and water content were $40 \times 40 \times 40 \mathrm{~mm}$, and the samples were cured to the desired age at $20 \pm 1{ }^{\circ} \mathrm{C}$ and $90 \%$ relative humidity $(\mathrm{RH})$. The moisture on the surface of the samples was wiped within $30 \mathrm{~s}$ and the mass values of the samples were determined. Then, the samples were dried at $100 \pm 5{ }^{\circ} \mathrm{C}$ to a constant weight, and the mass values of the samples were determined again. For the above tests, 3 specimens were tested in each group, and the average value was taken as the final test result.

Table 4. The design of mix proportions of cement paste.

\begin{tabular}{|c|c|c|c|c|c|c|}
\hline Groups & GBFS/wt.\% & FG $^{1 / w t .} \%$ & FGDG $2 / w t . \%$ & $\begin{array}{c}\text { NaOH Alkali } \\
\text { Concentration } 3 / \%\end{array}$ & $\begin{array}{c}\text { Water/Material } \\
\text { Ratio }\end{array}$ & Density $/ \mathrm{g} \cdot \mathrm{cm}^{-3}$ \\
\hline$S$ & 100 & 0 & 0 & \multirow{11}{*}{5} & \multirow{11}{*}{0.5} & 2.86 \\
\hline FG-5 & 95 & 5 & & & & 2.66 \\
\hline FG-10 & 90 & 10 & & & & 2.64 \\
\hline FG-15 & 85 & 15 & - & & & 2.63 \\
\hline FG-20 & 80 & 20 & & & & 2.62 \\
\hline FG-25 & 75 & 25 & & & & 2.60 \\
\hline FGDG-3 & 97 & \multirow{5}{*}{-} & 3 & & & 2.64 \\
\hline FGDG-6 & 94 & & 6 & & & 2.64 \\
\hline FGDG-9 & 91 & & 9 & & & 2.63 \\
\hline FGDG-12 & 88 & & 12 & & & 2.60 \\
\hline FGDG-15 & 85 & & 15 & & & 2.59 \\
\hline
\end{tabular}

${ }^{1}$ FG-fluorogypsum. ${ }^{2}$ FGDG-FGD gypsum. ${ }^{3} \mathrm{NaOH}$ alkali concentration is $\mathrm{m}_{\mathrm{Na} 2 \mathrm{O}} / \mathrm{m}_{\mathrm{GBFS}}$.

The XRD analysis was conducted using a Smart-lab type X-ray diffractometer, supplied by the Rigaku Co., Ltd. in Japan. The diffractometer employed a Cu- $\mathrm{K}_{\alpha}$ target and scanned the ranged of $5-70^{\circ}$ with the scanning rate of $10^{\circ} / \mathrm{min}$. Moreover, thermogravimetric-differential thermal analysis (TG-DTA) was conducted using an HCT-3 differential thermal balance produced by the Hengjiu Instrument Co., Ltd. in China. The analysis was conducted within the temperature range of $25-800{ }^{\circ} \mathrm{C}$, whereas the heating 
rate was $10{ }^{\circ} \mathrm{C} / \mathrm{min}$. Hydration heat was characterized using TAM Air type 8-channel hydration micro-calorimeter, which was manufactured by the TA Instruments Co., Ltd. in USA. The hydration heat analysis was conducted by collecting the continuous hydration heat of paste for 3 days. Additionally, the SEM-EDS analysis was conducted using a Merlin Compact field emission scanning electron microscope that was supplied by the Zeiss Co., Ltd. in Germany. Mercury intrusion porosimetry (MIP) was conducted using an AutoPore IV 9510 type automated mercury porosimeter that was obtained from Micromeritics Co., Ltd. (Norcross, GA) in USA.

\section{Results}

\subsection{Setting Time}

The variation in paste setting time is shown in Figure 3. It can be seen that, with the increase in the content of gypsum, the initial and final setting times were obviously prolonged. Compared with the FGD gypsum, FG had a more significant effect on the final setting time. When the contents of both the gypsums (FG and FGD gypsum) were $15 \mathrm{wt} . \%$ each, the initial setting time of FG and FGD gypsum was prolonged to 64 and $71 \mathrm{~min}$, respectively (compared to $8 \mathrm{~min}$ for the control sample), whereas the final setting time was prolonged from $31 \mathrm{~min}$ (for the control sample) to 182 and $85 \mathrm{~min}$, respectively. Meanwhile, the time interval between the initial and final settings of paste containing FGD gypsum became shorter. The poor solubility of FG and the weaker hydration reaction were the main reasons for the longer final setting time of the paste [8,12,15]. Moreover, FGD gypsum also prolonged the setting time of the paste, which was more due to the involvement of dissolved $\mathrm{SO}_{4}{ }^{2-}$ in the reaction to form ettringite on the particle surface that hindered the hydration reaction in a short time period [18]. This may be the inherent reason for the difference in the setting times of the two gypsums.

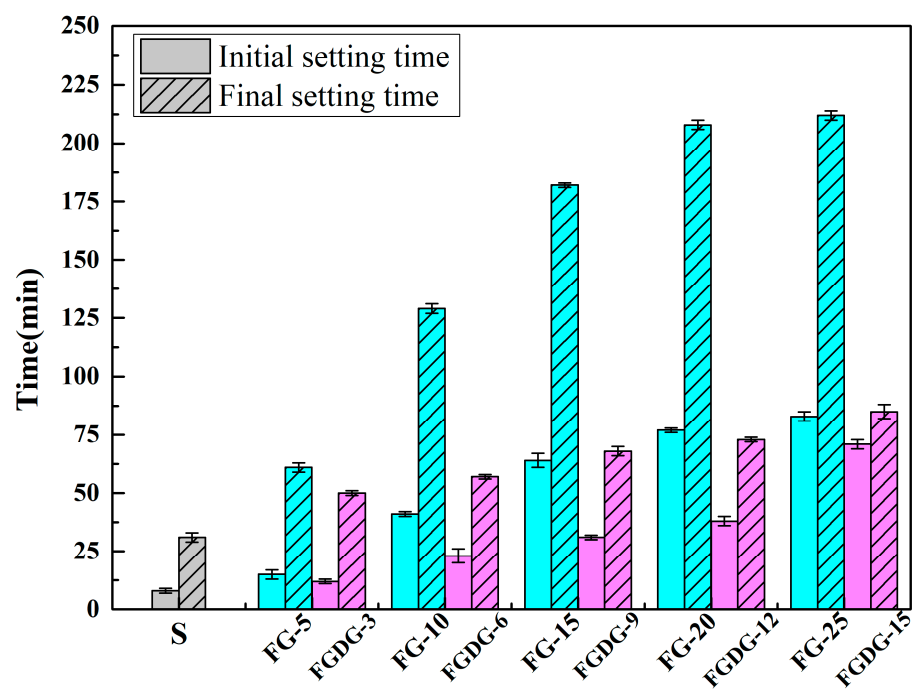

Figure 3. Effect of different gypsum content on setting time of paste.

\subsection{Compressive Strength}

The variation pattern of the compressive strengths of the hardened pastes with different gypsum contents is shown in Figure 4. The compressive strengths first increased, and then decreased with the increase in gypsum content. As shown in Figure 4a, when the FG content was $5 \mathrm{wt} . \%$, the compressive strength was the highest, and had the values of 23.1, 29.3 and $32.0 \mathrm{MPa}$ at 3, 7 and 28 days, respectively, which were $59.3 \%, 63.7 \%$ and $24.5 \%$ higher than the control sample.

Similarly, as shown in Figure 4b, when the content of FGD gypsum was 6 wt.\%, the compressive strength of the system was the highest, and had the values of $24.2 \mathrm{MPa}$, 
27.1 MPa and 34.4 MPa at 3, 7 and 28 days, respectively, which were $66.9 \%, 51.4 \%$ and $33.9 \%$ higher than the control sample.

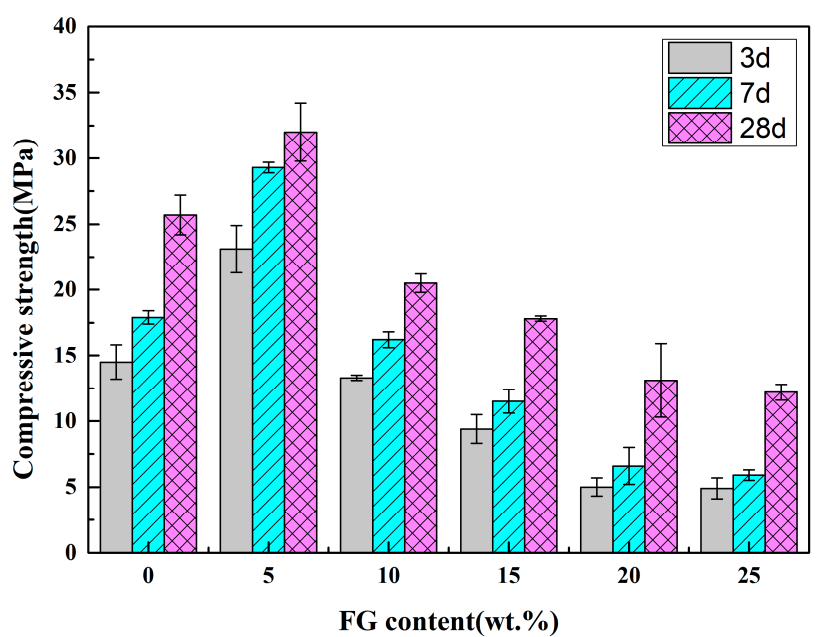

(a)

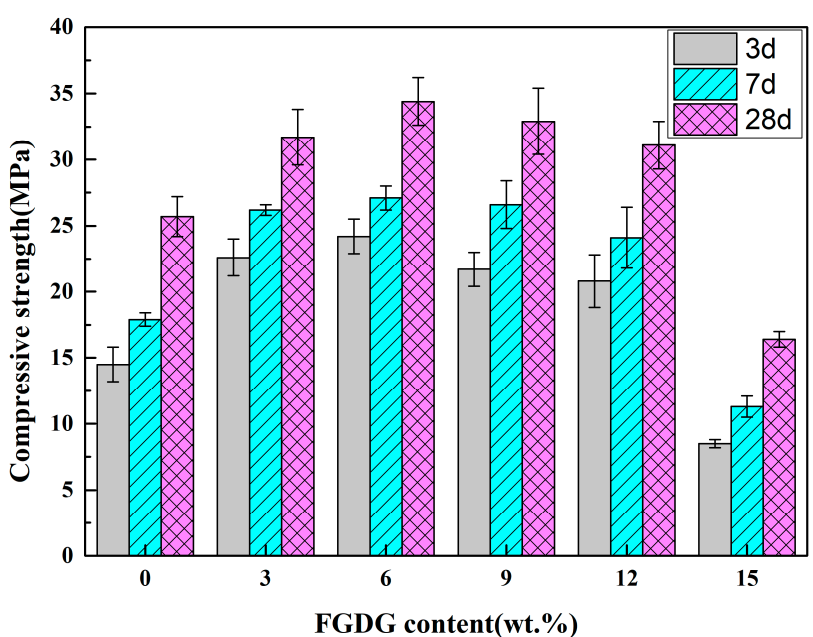

(b)

Figure 4. Compressive strength results with different gypsum content: (a) FG; (b) FGDG.

\subsection{Mass Change and Water Content}

Variation in the mass of hardened cement paste is shown in Figure 5. The mass of hardened cement paste increased with the increase of gypsum content. As the content of gypsum increased, more $\mathrm{Ca}^{2+}$ and $\mathrm{SO}_{4}{ }^{2-}$ ions were provided for the hydration reaction, which were conducive to the formation of ettringite. In addition, the formation of $\mathrm{Na}_{2} \mathrm{SO}_{4}$ will also lead to an increase in the mass of the hardened cement. When the content of FG was more than $15 \mathrm{wt} . \%$, the mass of the sample increased significantly. Due to the curing in a wet environment, the formation of a large amount of ettringite caused the sample to crack (in Figure 6). Due to this reason, the moisture could easily penetrate the interior of the sample.

Figure 7 shows the results of the water content of the samples. The water content of the sample first decreased, and then, increased with the increase of gypsum content. After the first day, the water content was higher because the initial hydration reaction was insufficient and there was more free water in the samples. With the increase in age, free water gradually transformed into combined water of ettringite and gels, and therefore, the water contents of the samples gradually increased.

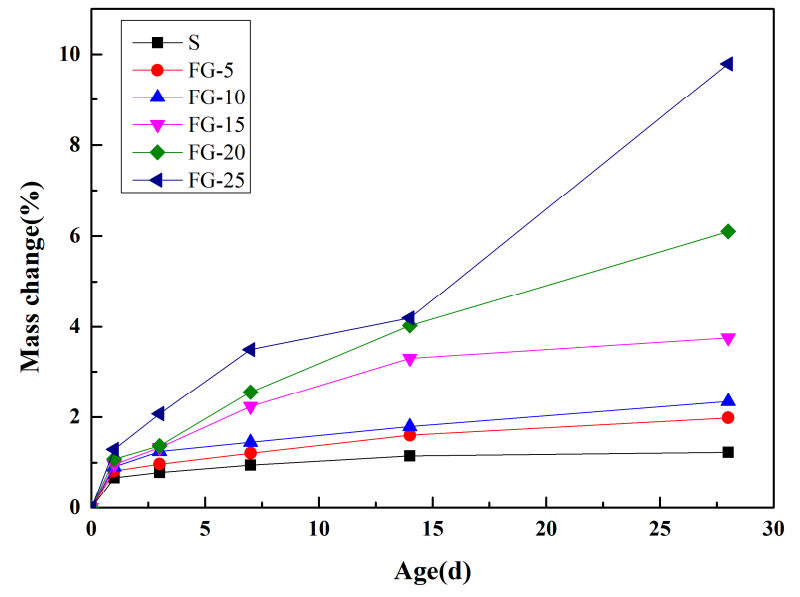

(a)

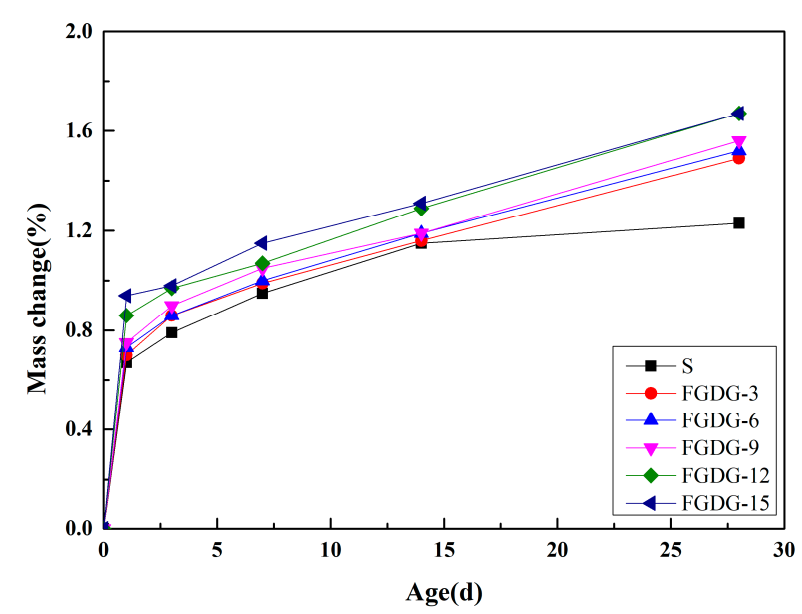

(b)

Figure 5. Effect of two types of gypsum on mass change results: (a) FG; (b) FGDG. 


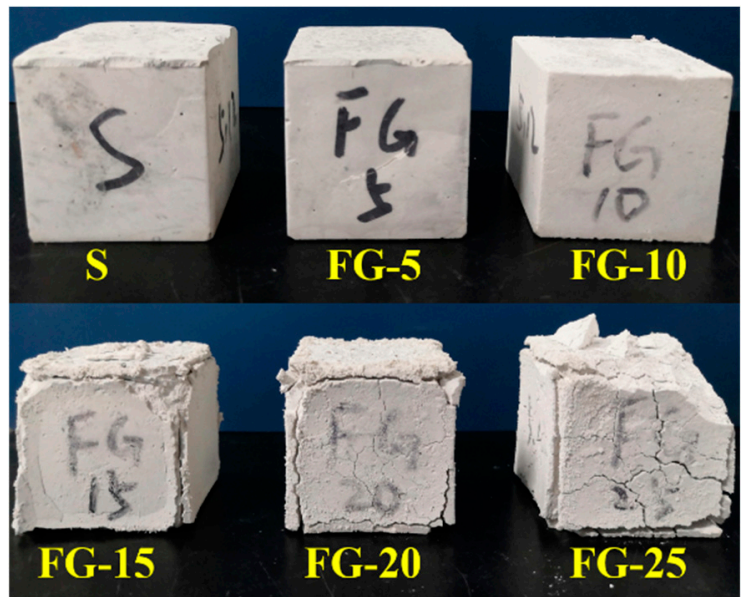

(a)

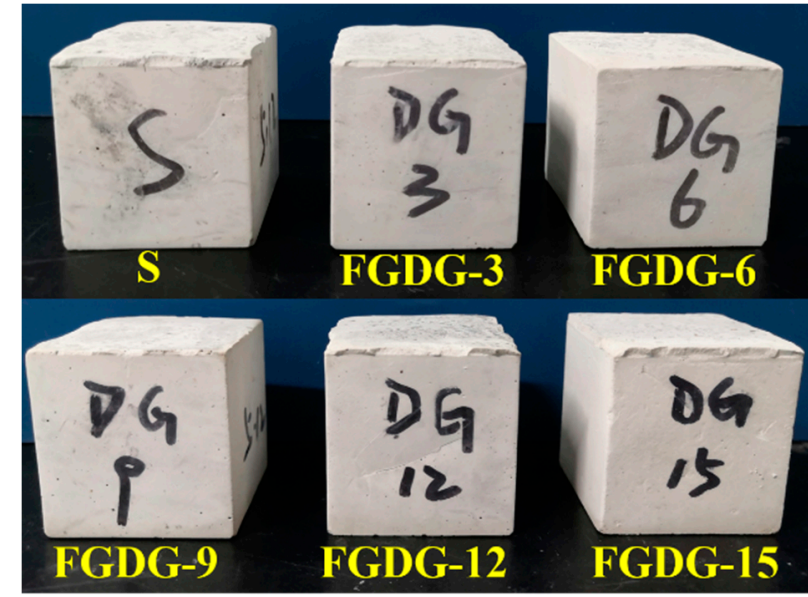

(b)

Figure 6. Samples at 28 days with different gypsum content after drying at $100{ }^{\circ} \mathrm{C}$ : (a) FG; (b) FGDG.

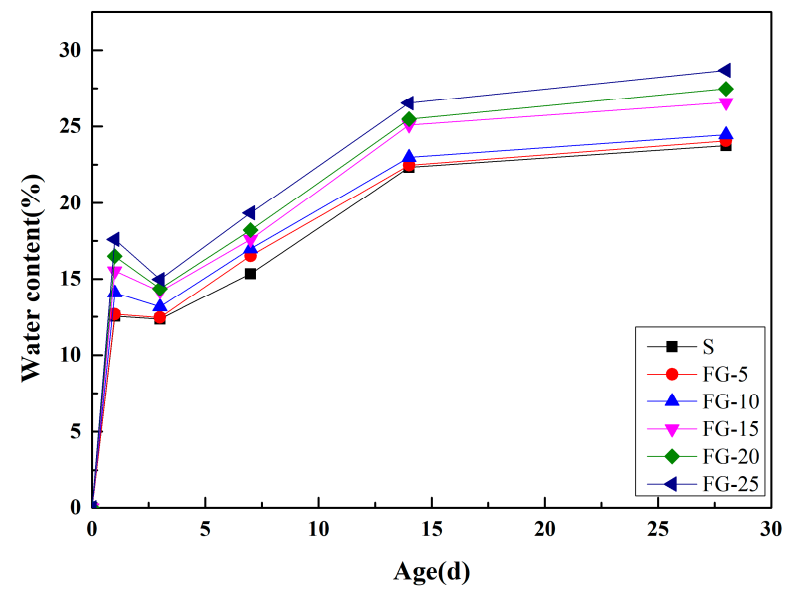

(a)

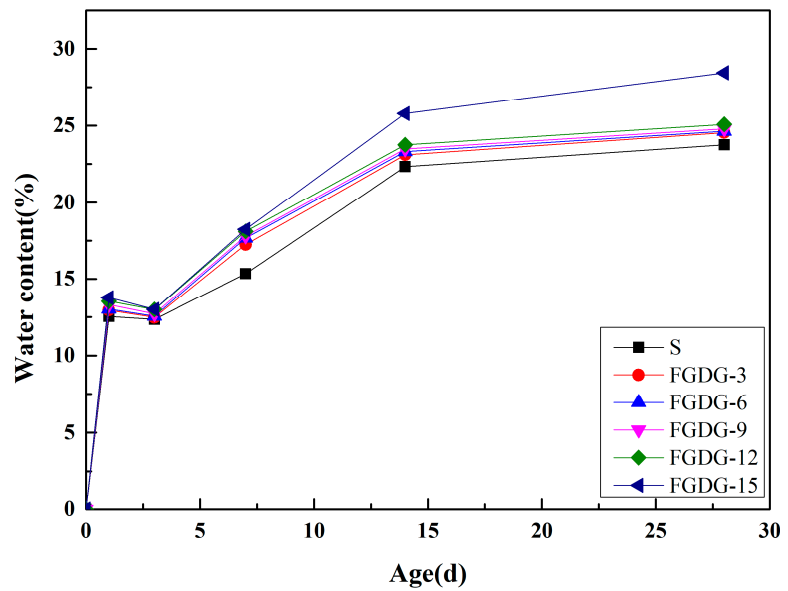

(b)

Figure 7. Effect of two types of gypsum on water content results: (a) FG; (b) FGDG.

\subsection{Analysis of the Mechanism \\ 3.4.1. XRD Analysis}

The XRD analyses of the cement paste at 3 and 28 days with different gypsum contents are shown in Figures 8 and 9. As shown in Figure 8a, the main hydration products of the cement paste after 3 days were ettringite $(\mathrm{AFt}), \mathrm{Ca}(\mathrm{OH})_{2}, \mathrm{C}-\mathrm{A}-\mathrm{S}-\mathrm{H}$ gel and $\mathrm{Na}_{2} \mathrm{SO}_{4}$. With the increase of FG content, the diffraction peak of ettringite $\left(2 \theta=9^{\circ}\right)$ was obviously enhanced, whereas the diffraction peak of $\mathrm{Ca}(\mathrm{OH})_{2}\left(2 \theta=34^{\circ}\right)$ had no obvious change. The diffraction peaks of C-A-S-H gel weakened, especially in the $(002)$ crystal plane $\left(2 \theta=7^{\circ}\right)$ and $(110)$ crystal plane $\left(2 \theta=29^{\circ}\right)$. This shows that, under strong alkaline excitation, when the $\mathrm{SO}_{4}{ }^{2-}$ ions were sufficient, more of the $\mathrm{Ca}^{2+}$ ions transformed into ettringite. Moreover, free $\mathrm{Na}^{+}$in the hydration reaction reacted with $\mathrm{SO}_{4}{ }^{2-}$ to form $\mathrm{Na}_{2} \mathrm{SO}_{4}\left(2 \theta=19^{\circ}\right)$. As the curing time increased, the degree of the hydration of cement became deepened, and the overall diffraction peak in Figure $8 \mathrm{~b}$ became stronger. In addition, new hydration products also appeared in the spectra. The product in the cement paste underwent a certain carbonation reaction, and the characteristic diffraction peak of $\mathrm{CaCO}_{3}$ appeared $\left(2 \theta=29^{\circ}\right)$. The $\mathrm{Al}_{2} \mathrm{O}_{3}$ content in the GBFS was relatively high, and $\mathrm{C}(\mathrm{N})-\mathrm{A}-\mathrm{S}-\mathrm{H}$ gel $\left(2 \theta=28^{\circ}\right)$ was gradually formed during the alkali-excited reaction that was stimulated by $\mathrm{NaOH}$ and led to a decrease in the purity of C-A-S-H gel and the shift of diffraction peaks [33]. When 
the content of FG was high (FG-25), the anhydrite and water in the paste transformed into $\mathrm{CaSO}_{4} \cdot 2 \mathrm{H}_{2} \mathrm{O}\left(2 \mathrm{\theta}=12^{\circ}\right)$.

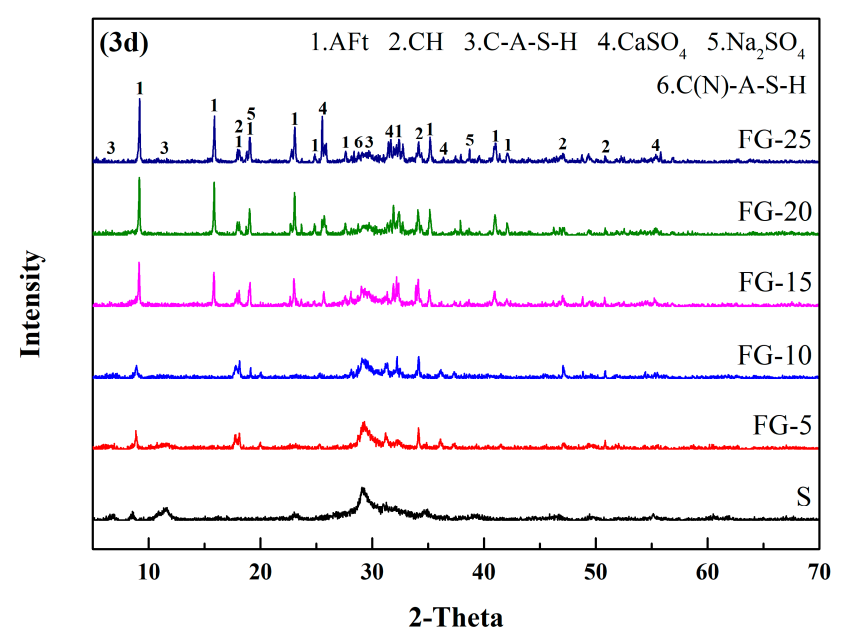

(a)

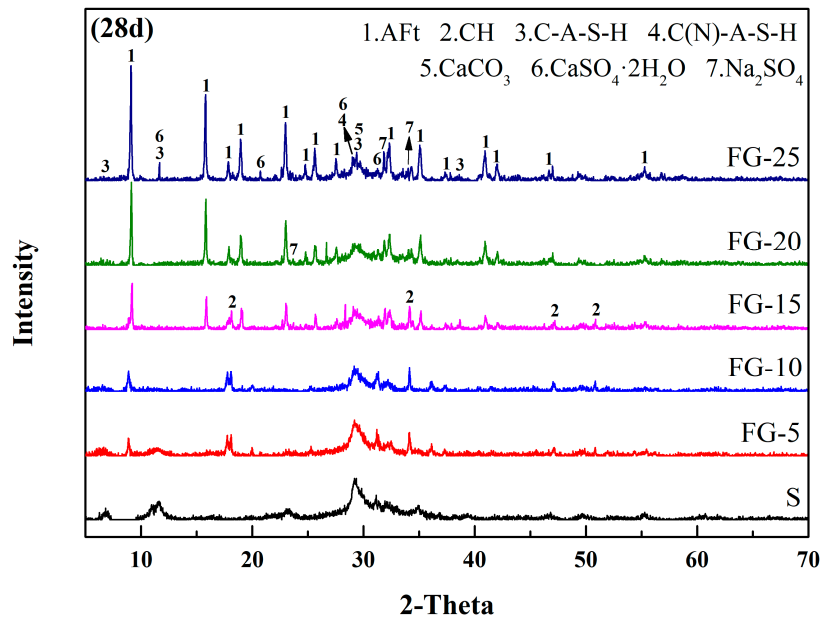

(b)

Figure 8. XRD patterns of cement paste with different FG content: (a) 3 days; (b) 28 days.

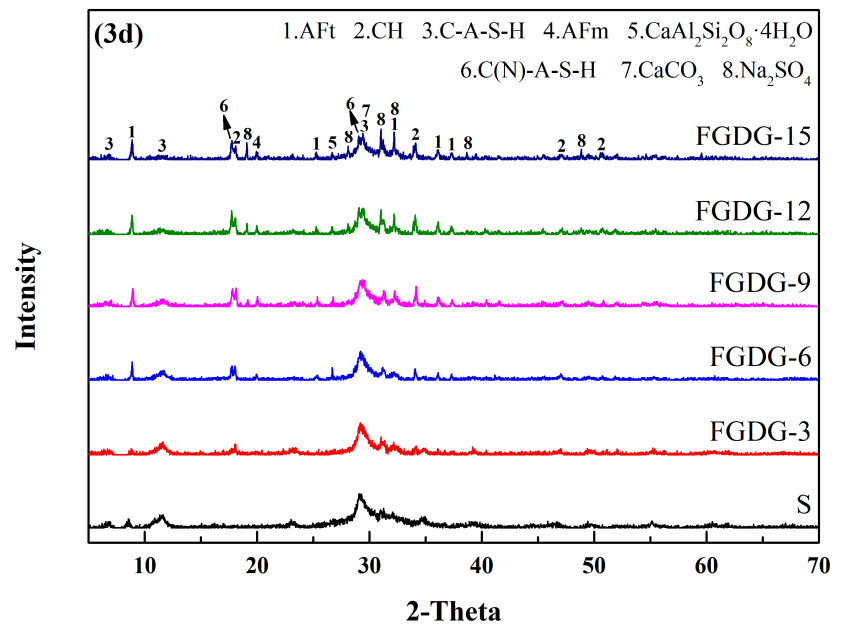

(a)

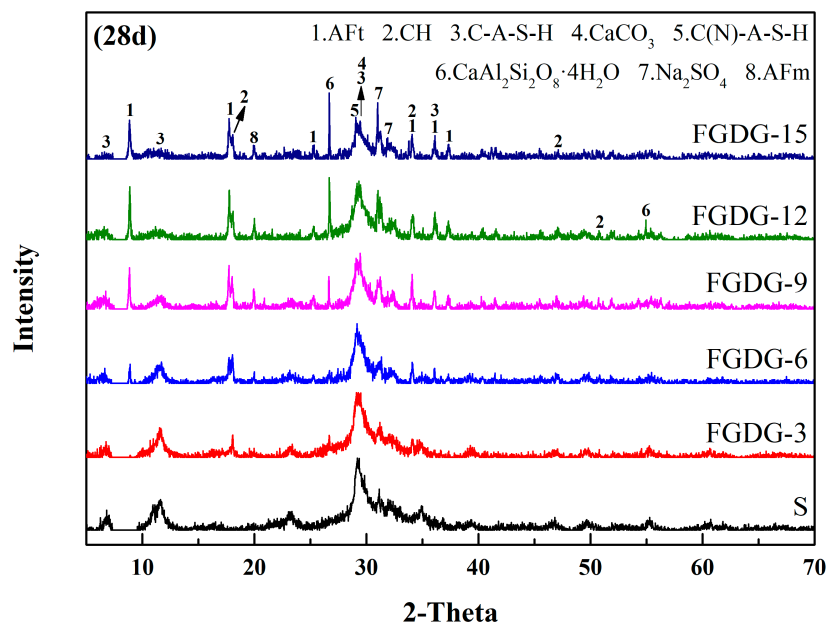

(b)

Figure 9. XRD patterns of cement paste with different FGDG content: (a) 3 days; (b) 28 days.

As shown in Figure 9, the main hydration products of the paste included ettringite, $\mathrm{Ca}(\mathrm{OH})_{2}, \mathrm{C}-\mathrm{A}-\mathrm{S}-\mathrm{H}$ gel, $\mathrm{C}(\mathrm{N})-\mathrm{A}-\mathrm{S}-\mathrm{H}$ gel and $\mathrm{Na}_{2} \mathrm{SO}_{4}$. However, different from $\mathrm{FG}$, the conversion from AFt to AFm $\left(2 \theta=20^{\circ}\right)$ appeared at 3 days, and the new hydration product of gismondine $\left(\mathrm{CaAl}_{2} \mathrm{Si}_{2} \mathrm{O}_{8} \cdot 4 \mathrm{H}_{2} \mathrm{O}, 2 \theta=26^{\circ}\right)$ was formed, which was consistent with some previously reported results [34-36]. In addition, the diffraction peaks of $\mathrm{CaCO}_{3}, \mathrm{C}-(\mathrm{A})-\mathrm{S}-\mathrm{H}$ gel and $\mathrm{C}(\mathrm{N})-\mathrm{A}-\mathrm{S}-\mathrm{H}$ gel also appeared after three days. After 28 days (Figure $9 \mathrm{~b}$ ), the hydration products did not change, and only the intensity of the diffraction peak became stronger than that after 3 days. The relevant hydration reaction can be represented by Reaction Equations (1) and (2).

$$
\begin{gathered}
2\left\{\mathrm{Ca}_{3} \mathrm{Al}(\mathrm{OH})_{6} \cdot 12 \mathrm{H}_{2} \mathrm{O}\right\}^{3+}+3 \mathrm{SO}_{4}{ }^{2-}+2 \mathrm{H}_{2} \mathrm{O} \rightarrow 3 \mathrm{CaO} \cdot \mathrm{Al}_{2} \mathrm{O}_{3} \cdot 3 \mathrm{CaSO}_{4} \cdot 32 \mathrm{H}_{2} \mathrm{O} \\
\mathrm{CaSO}_{4}+2 \mathrm{NaOH} \rightarrow \mathrm{Na}_{2} \mathrm{SO}_{4}+\mathrm{Ca}(\mathrm{OH})_{2}
\end{gathered}
$$




\subsubsection{TG-DTA Analysis}

Figures 10 and 11 show the TG-DTA results of the cement pastes with different contents of FG and FGD gypsum. As shown in Figure 10a, the first endothermic peak of the paste appeared at about $110^{\circ} \mathrm{C}$ after three days, which was formed by the loss of combined water of AFt and gels. The second endothermic peak appeared at about $450{ }^{\circ} \mathrm{C}$, which was formed by the loss of combined water by $\mathrm{Ca}(\mathrm{OH})_{2}$ crystals. With the increase in the content of FG, the rate of the loss of mass of the paste at $110^{\circ} \mathrm{C}$ gradually increased. Meanwhile, the rate of the loss of the mass of the control sample was $4.88 \%$. When the gypsum content was $25 \mathrm{wt} . \%$, the rate of the loss of the mass reached $8.07 \%$. In addition, with the increase in the content of the gypsum, the first endothermic peak gradually shifted to the right-hand side, which indicates that the loss of combined water was mainly from the gel to ettringite. This change is also consistent with the XRD results. On the 28th day of the curing (Figure 10b), the degree of the hydration of the paste deepened, and a new endothermic peak appeared at $270{ }^{\circ} \mathrm{C}$, which was formed by the transformation of $\mathrm{Na}_{2} \mathrm{SO}_{4}$ from the orthorhombic system to the hexagonal crystal system. The overall loss of the mass of the paste increased; however, the variation pattern remained unchanged.

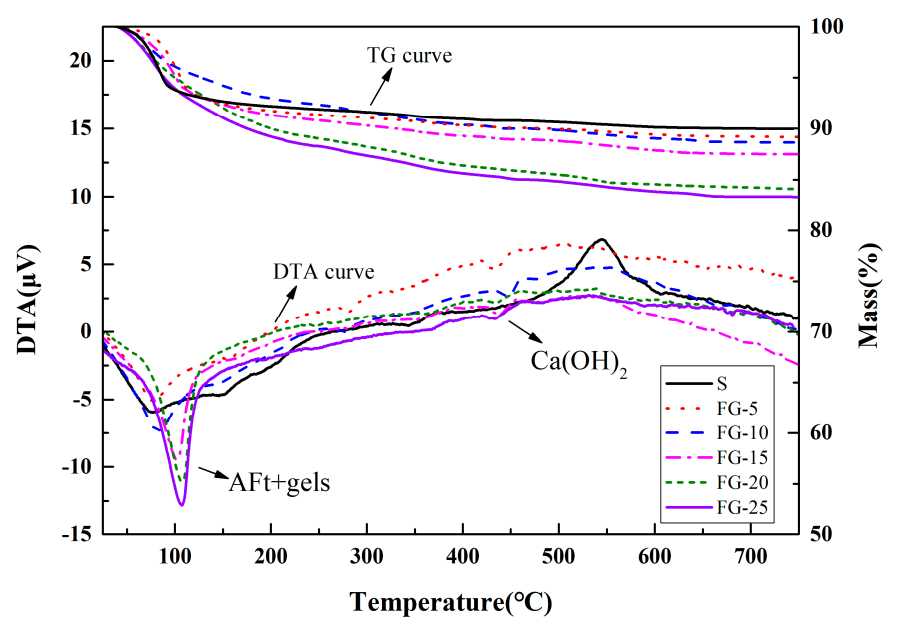

(a)

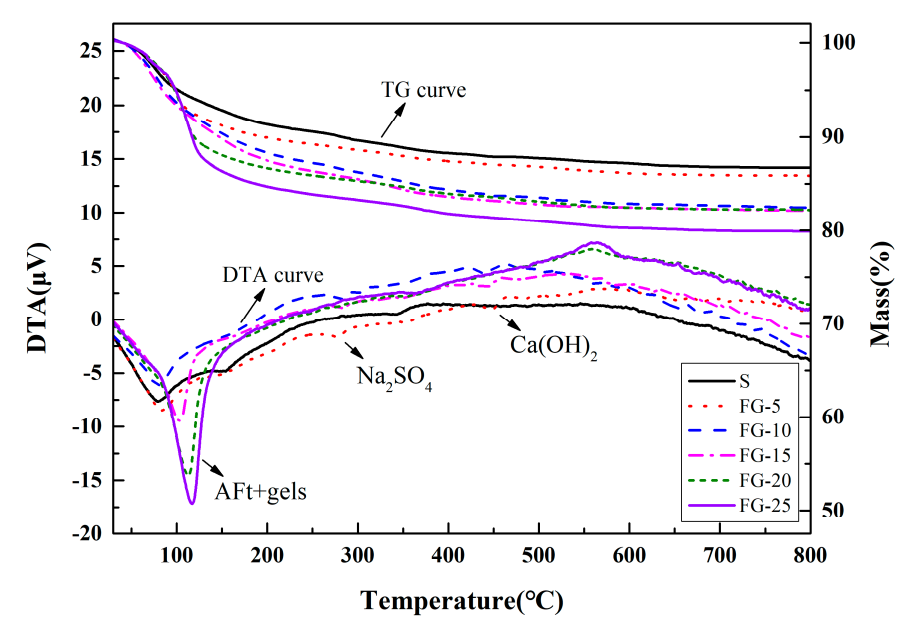

(b)

Figure 10. TG-DTA results of cement paste with different FG content: (a) 3 days; (b) 28 days.

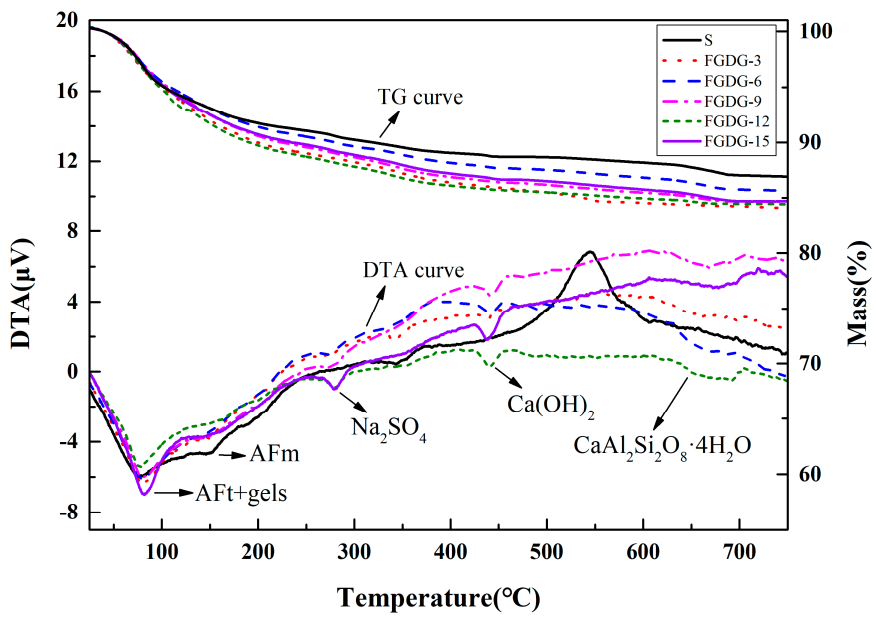

(a)

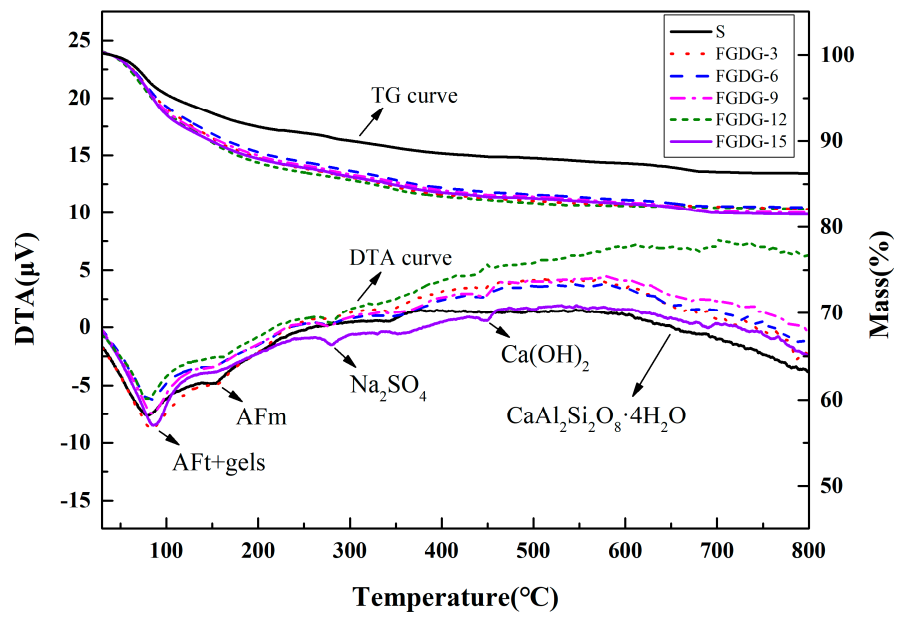

(b)

Figure 11. TG-DTA results of cement paste with different FGDG content: (a) 3 days; (b) 28 days.

For different contents of FGD gypsum, the endothermic peaks of 110,270 and $450{ }^{\circ} \mathrm{C}$ still existed for the cement paste, as shown in Figure 11. Different from FG, after curing 
for 3 days, the endothermic peak for the loss of bound water for AFm appeared at about $160{ }^{\circ} \mathrm{C}$ The endothermic peak for the loss of combined water for gismondine appeared at about $700{ }^{\circ} \mathrm{C}$. The rate of the loss of mass increased with the increase in the content of FGD gypsum. When curing for 28 days, the overall rate of the loss of mass increased, while the endothermic peak of $\mathrm{Ca}(\mathrm{OH})_{2}$ weakened though the overall variation pattern remained the same.

\subsubsection{Analysis of the Hydration Heat}

Gypsum directly affected the progress of hydration reaction in the cement paste, whereas the release of cumulative heat changed, as shown in Figure 12. As shown in Figure 12a, the cumulative heat release of the paste after mixing with FG decreased with the increase of the amount of mixing. The method of incorporation of gypsum reduced the content of GBFS, which also led to a decrease in the amount of heat released during the hydration reaction after alkali excitation. Meanwhile, the amount of heat released during the new formation of ettringite was insufficient to compensate for this part of the heat loss. Therefore, the cumulative heat release of the control sample was higher than the other samples (with FG and FGD gypsum). At the same time, when the content of FG was $15 \mathrm{wt} . \%$ or higher, the cumulative heat release increased slowly before $26 \mathrm{~h}$, forming a process similar to the "stability period". This is still due to the poor solubility of anhydrite, which took longer to mobilize the activity, due to which the accumulated heat increased rapidly (see Equations (3) and (4)) [8].

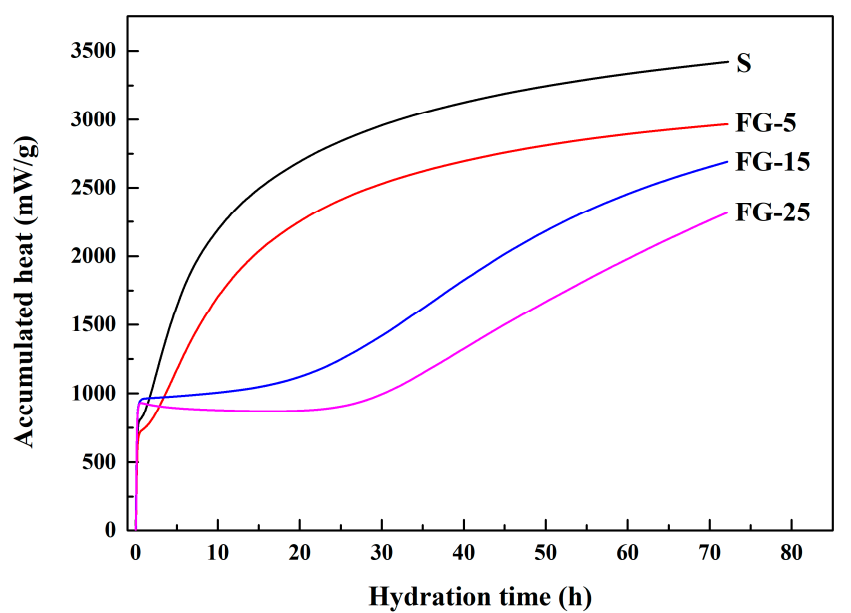

(a)

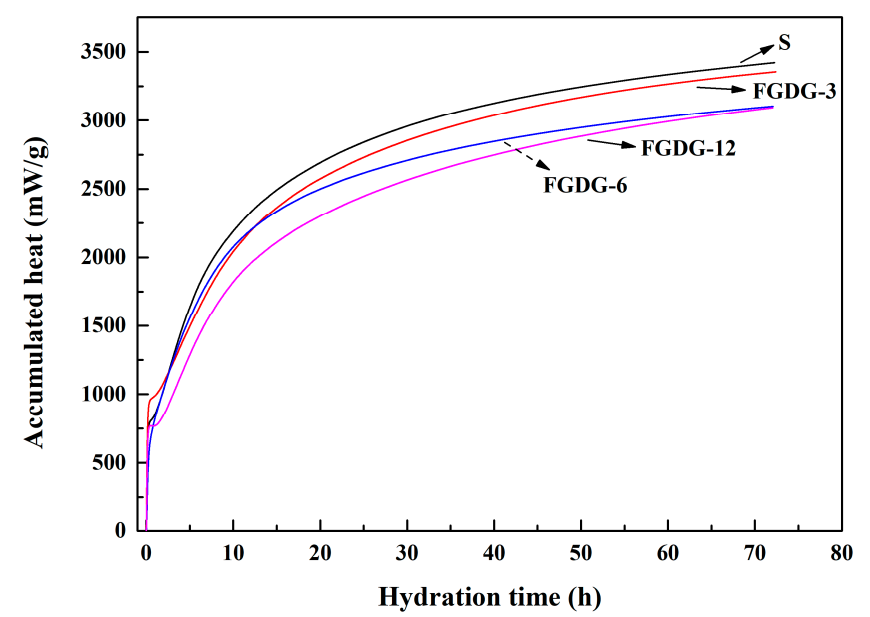

(b)

Figure 12. Effect of different gypsum content on accumulated heat of cement paste: (a) FG; (b) FGDG.

As shown in Figure 12b, the accumulated heat of the paste decreased with the increase in the content of FGD gypsum. However, the cumulative heat release of the paste mixed with the FGD gypsum was significantly higher than that of the paste mixed with FG, and the cumulative heat release curve was significantly different from that of FG. This is because FGD gypsum was easier to participate during the hydration reaction than the FG.

$\mathrm{mCaSO}_{4}$ (Anhydrite) + Activator $\cdot \mathrm{nH}_{2} \mathrm{O} \rightarrow$ Activator $\cdot \mathrm{mCaSO}_{4} \cdot \mathrm{nH}_{2} \mathrm{O}$ (unstable double salt)

Activator $\cdot \mathrm{mCaSO}_{4} \cdot \mathrm{nH}_{2} \mathrm{O} \rightarrow \mathrm{mCaSO}_{4} \cdot 2 \mathrm{H}_{2} \mathrm{O}($ Gypsum $)+$ Activator $\cdot(\mathrm{n}-2 \mathrm{~m}) \mathrm{H}_{2} \mathrm{O}$

\subsubsection{SEM-EDS Analysis}

The secondary electron images of the paste after 3 and 28 days with different contents of FG and FGD gypsum are shown in Figures 13 and 14. As shown in Figure 13, the control sample was the gel layer, whereas unreacted particles formed after the alkaline excitation of GBFS. After the FG was mixed, short rod-shaped AFt and $\mathrm{Ca}(\mathrm{OH})_{2}$ crystals 
were formed. As the gypsum content increased, the amount of AFt crystals increased and the morphology changed to fine needles. When the FGD gypsum was mixed, AFt crystal clusters were also formed in the paste. When the gypsum content was large, it was easy to observe the precipitation of $\mathrm{Na}_{2} \mathrm{SO}_{4}$ crystals on the surface of hydrated products or the surface of un-hydrated particles. In addition, the EDS analysis (shown in Figure 15) showed that the chemical composition of the gels on the sample surface changed. The incorporation of gypsum caused the gels to change from $\mathrm{C}-\mathrm{A}-\mathrm{S}-\mathrm{H}$ gel (in the control sample) to C(N)-A-S-H gel. Furthermore, when FGD gypsum was incorporated, the $\mathrm{Na}^{+}$ content in the gels became higher.

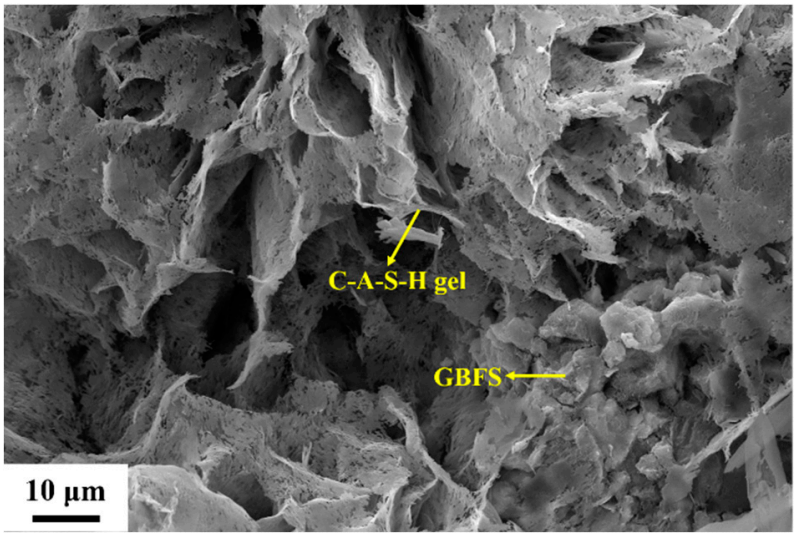

(a)

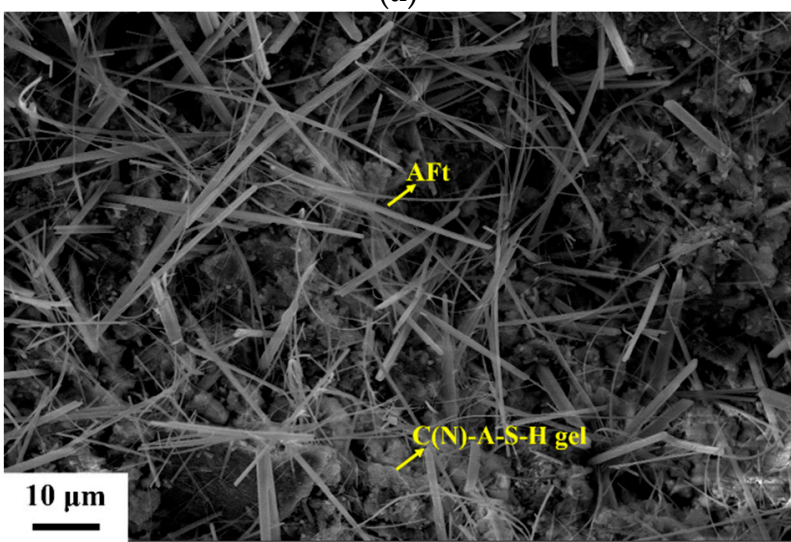

(c)

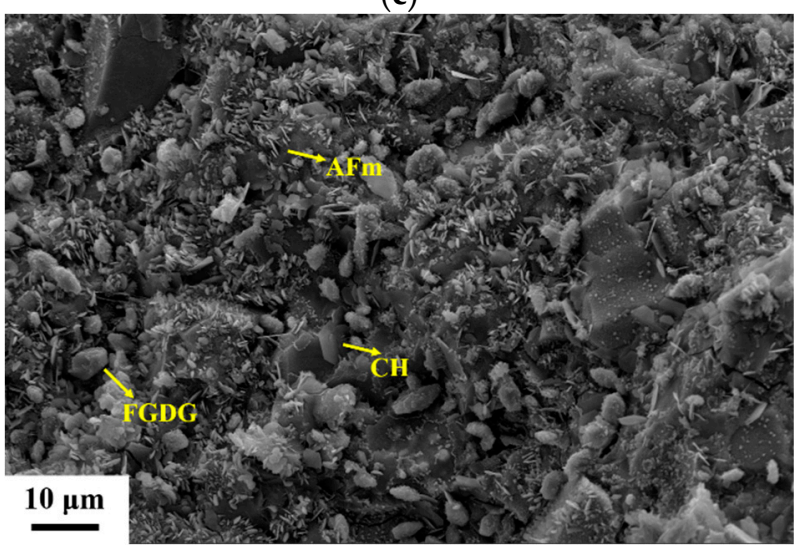

(e)

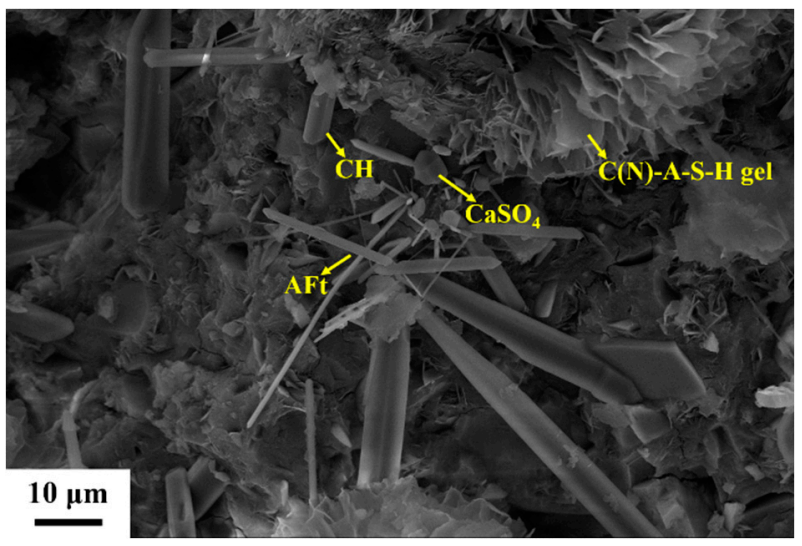

(b)

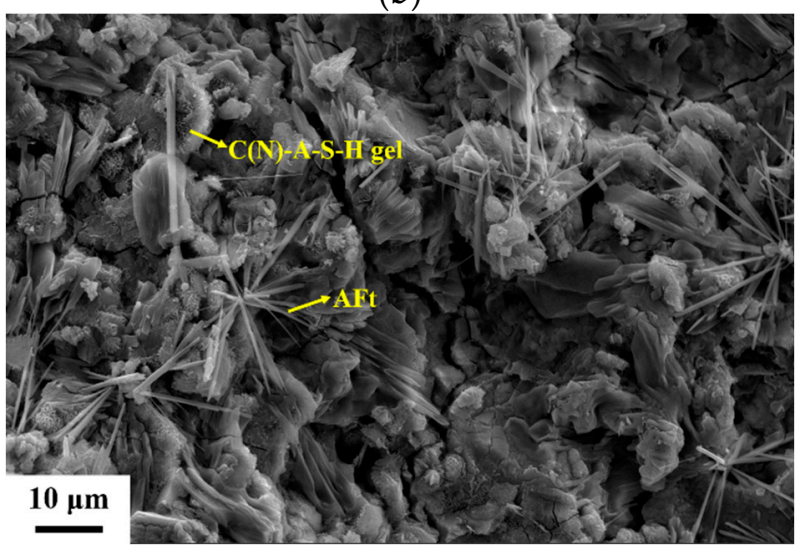

(d)

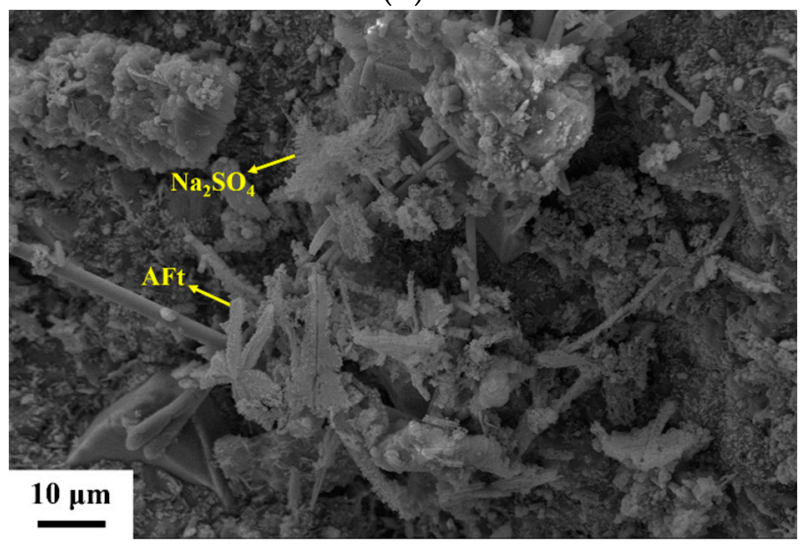

(f)

Figure 13. SEM test of the cement paste at 3 days: (a) S; (b) FG-5; (c) FG-25; (d) FGDG-3; (e) FGDG-6; (f) FGDG-12. 


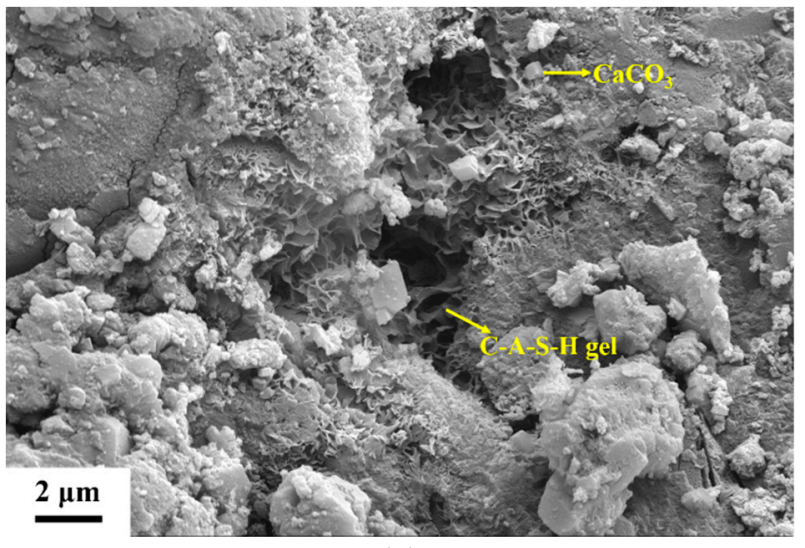

(a)

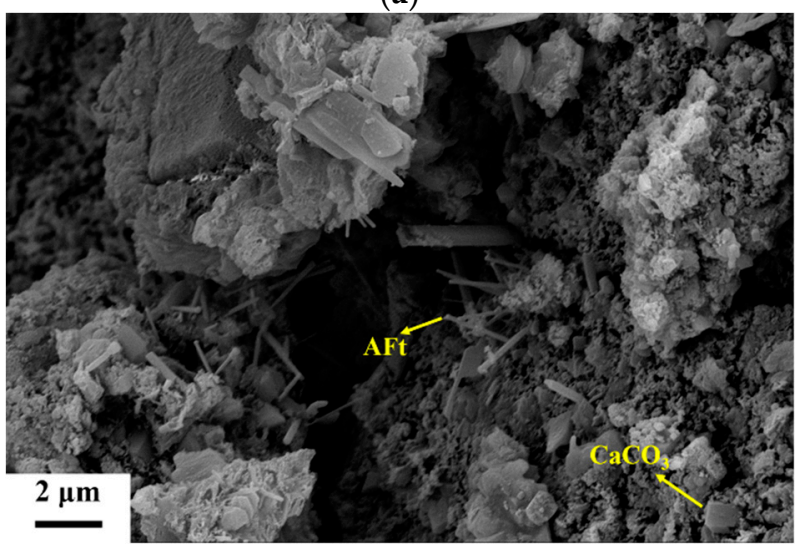

(c)

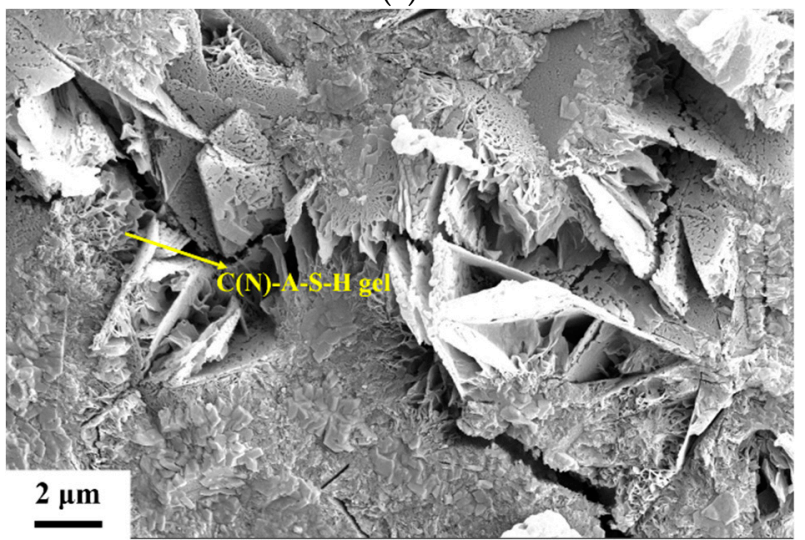

(e)

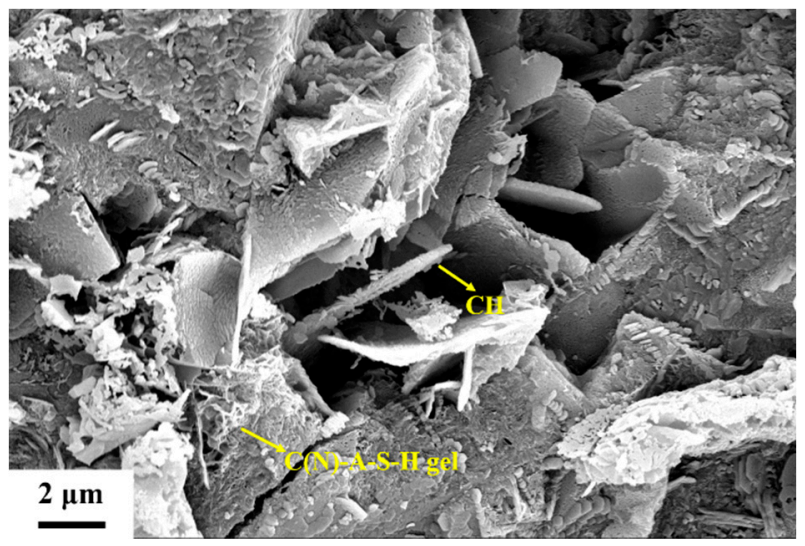

(b)

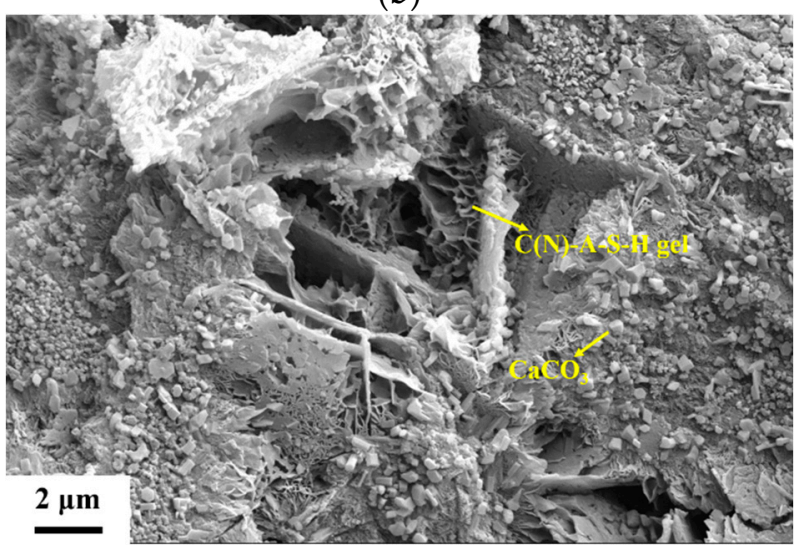

(d)

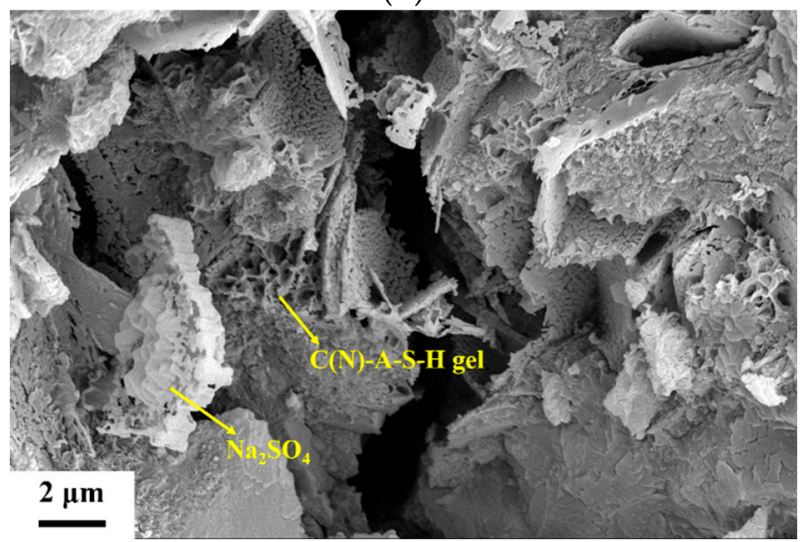

(f)

Figure 14. SEM test of the cement paste at 28 days: (a) S; (b) FG-5; (c) FG-25; (d) FGDG-3; (e) FGDG-6; (f) FGDG-12.

As shown in Figure 14, with the increase in the curing period, the morphology of the paste tended to coexist with AFt and gels. At the same time, a part of the $\mathrm{Ca}(\mathrm{OH})_{2}$ crystals was carbonized to form $\mathrm{CaCO}_{3}$. When the content of gypsum was high, it was difficult to observe obvious hydration products in the pastes, and more of them were covered by the $\mathrm{Na}_{2} \mathrm{SO}_{4}$ crystal layer. 


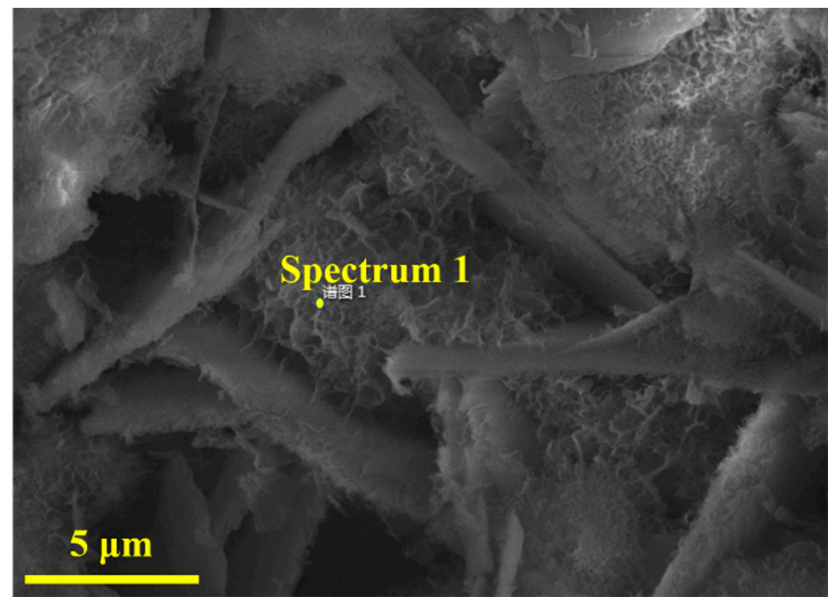

(a)

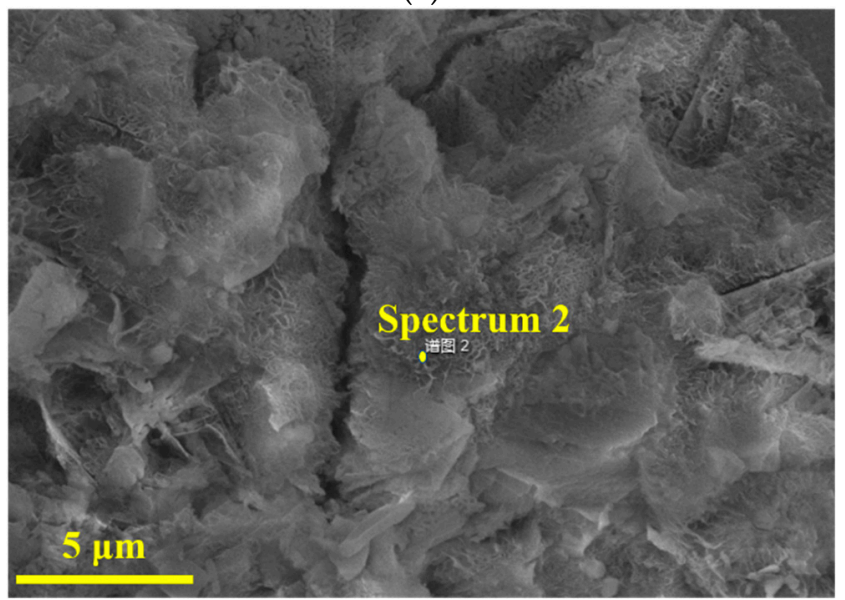

(c)

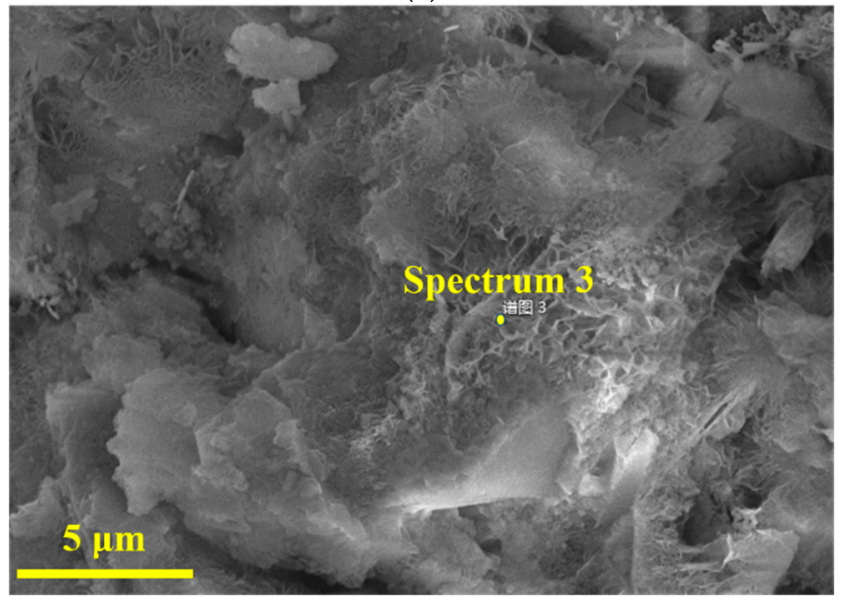

(e)

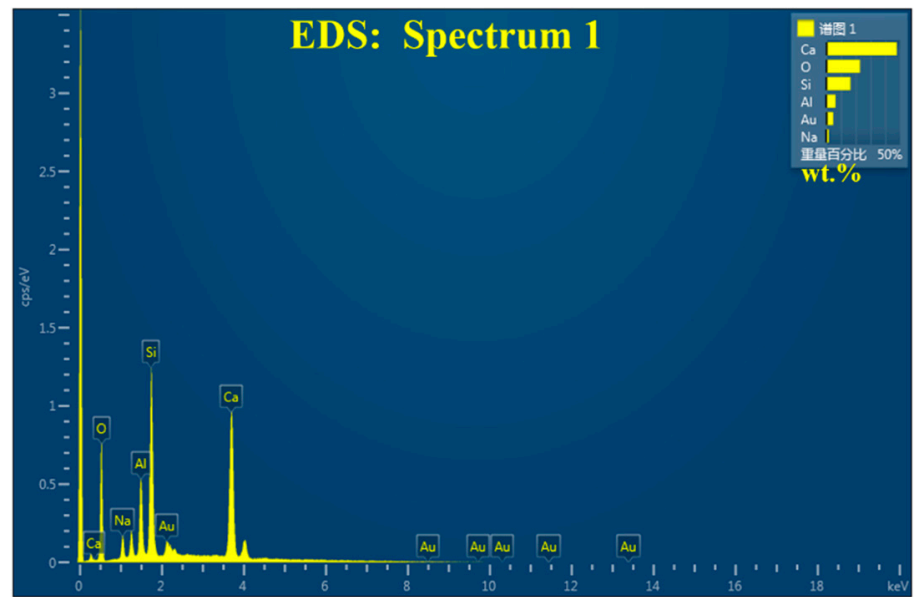

(b)

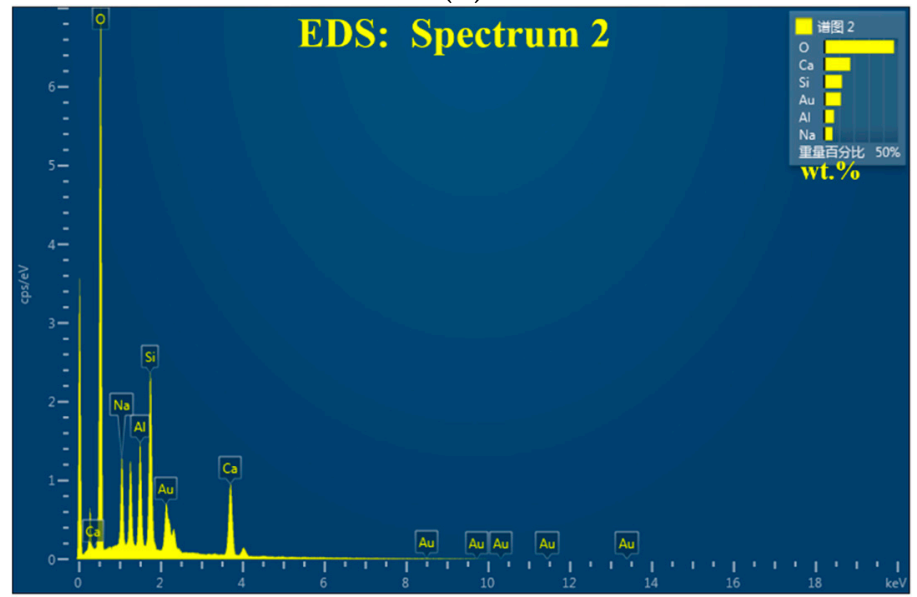

(d)

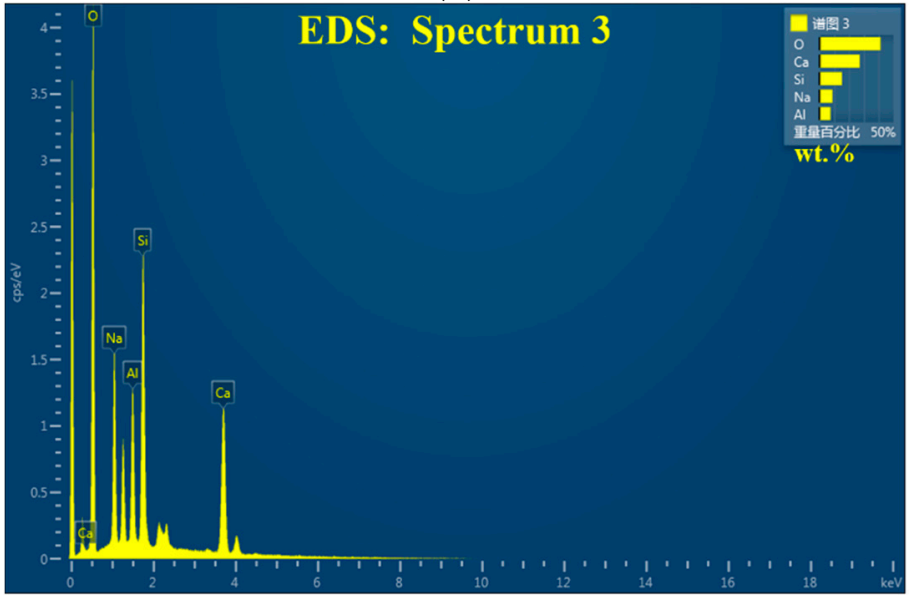

(f)

Figure 15. EDS test of the cement paste at 3 days: (a) Spectrum 1 of group S for EDS test; (b) EDS test result of spectrum 1; (c) Spectrum 2 of group FG-5 for EDS test; (d) EDS test result of spectrum 2; (e) Spectrum 3 of group FGDG-6 for EDS test;

(f) EDS test result of spectrum 3.

\subsubsection{MIP Analysis}

Figure 16 compares the pore size distribution of different samples after 28 days. When the contents of FG and FGD gypsum were 5 and $6 \mathrm{wt} \%$, respectively, the pore size distributions tended to be smaller than that of the control sample. According to the pore size classification $[37,38]$, the results presented in Table 5 show that the porosity of cement paste was significantly reduced after the incorporation of gypsum in the samples. 
Meanwhile, compared to the control sample, the proportion of pores with sizes higher than $100 \mathrm{~nm}$ was significantly reduced. The variation in porosity was consistent with the compressive strength, indicating that lower porosity had higher compressive strength. The formation of ettringite filled the pores left by the water after the hydration reaction, which led to a decrease in porosity and improved the compactness of the cement paste.

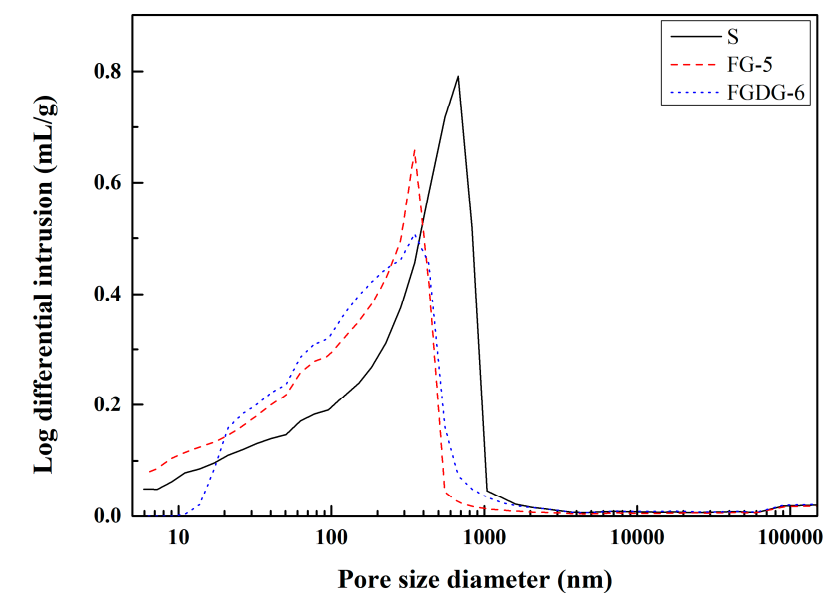

Figure 16. Pore size distribution of samples with different gypsum content at 28 days.

Table 5. Pore size distribution of samples at 28 days.

\begin{tabular}{ccccccc}
\hline \multirow{2}{*}{ Sample } & Porosity/\% & Average Pore Diameter/nm & \multicolumn{3}{c}{ Pore Size Distribution/\% } \\
\cline { 4 - 6 } & & & $<\mathbf{1 0} \mathbf{n m}$ & $\mathbf{1 0} \mathbf{5 0} \mathbf{~ n m ~}$ & $\mathbf{5 0 ~ 1 0 0 ~} \mathbf{n m}$ & $>\mathbf{1 0 0} \mathbf{~ n m}$ \\
\hline S & 57.12 & 90.31 & 2.60 & 12.41 & 7.94 & 77.05 \\
FG-5 & 55.82 & 53.00 & 4.84 & 19.59 & 13.57 & 62.00 \\
FGDG-6 & 53.64 & 84.59 & 0.00 & 17.30 & 14.86 & 67.84 \\
\hline
\end{tabular}

In summary, the main hydration product (ettringite) and micro-structure changed after the incorporation of gypsum in the cement, and therefore, it led to the difference in macroscopic properties such as compressive strength of the hardened cement paste. After gypsum was incorporated into the cement, the main hydration product changed from C(N)-A-S-H gel to AFt (Figures 8 and 9). Meanwhile, the formation of AFt in the micro-structure shows that the total porosity decreased, and the proportion of macropores (diameter $>100 \mathrm{~nm}$ ) decreased significantly. Furthermore, the proportions of gel (diameter $<10 \mathrm{~nm}$ ) and transitional pores (diameter of 10-100 nm) increased. Moreover, the average pore size decreased, and the micro-structure became denser, which was conducive to compressive strength [38]. Therefore, when the contents of FG and FGD gypsum were 5 and $6 \mathrm{wt} . \%$, respectively, the cement had higher compressive strength than those of the control sample.

Conversely, the amount of AFt increased with the increase of gypsum content (Figures 10 and 11), filled the pore space. However, excessive formation of AFt may lead to the expansion and cracking of the sample, increasing the mass and water content of the samples, especially when the content of FG was higher than $10 \mathrm{wt}$ \% (as shown in Figure 6). This was not conducive to the compressive strength. The macroscopic performance was manifested by the reduction of compressive strength.

\section{Discussion}

Through the summary and discussion of the above-mentioned literature, combined with the test results of this paper, it can be known that the current research on waste gypsum is more focused on the study of the type and content of waste gypsum on the setting, hardening and durability of cement-based materials. In order to further study the 
influence of waste gypsum on the performances of cement-based materials and improve the resource utilization of waste gypsum, research can be carried out in the following aspects:

(1) Research on the activation of hydration activity of waste gypsum. Compared with analytical reagent $\mathrm{CaSO}_{4}$ [39], the use of FG or FGD gypsum greatly increased the setting time of alkali slag cement. For ordinary Portland cement, the incorporation of gypsum can play a beneficial role in promoting the generation of hydration products and regulating the setting time. However, the optimal amount of waste gypsum to be used in alkali slag cement was relatively low. Once the limit value was exceeded, the compressive strength and setting time would deteriorate rapidly. After the dissolution of gypsum, the high concentration of $\mathrm{Ca}^{2+}$ ions in the liquid phase that would inhibit GBFS dissolution is thought to be the main reason [40]. Waste gypsum has low hydration activity, especially fluorogypsum with anhydrite as the main composition. Its hydration reaction is slow at early age and requires a long hydration time. The activation of waste gypsum and the hydration reaction process in cement-based materials and the formation mechanism of the microstructure remain to be studied. Some scholars [41] have studied the activation of waste gypsum, but its hydration reaction process in cement-based materials remains to be clarified.

(2) Research on the influence of impurity ions in waste gypsum on the hydration performance of cement-based materials. Different from natural gypsum, waste gypsum contains different kinds of impurity ions, such as $\mathrm{Na}^{+}, \mathrm{K}^{+}, \mathrm{F}^{-}$etc. The migration law of impurity ions in the hydration reaction process of cement-based materials and their occurrence state and mechanism in the hydration products need to be clarified. Moreover, what is the relationship between the macroscopic properties and microscopic properties of cement-based materials caused by impurity ions in waste gypsum? The evaluation mechanism of impurity ions in cement-waste gypsum cementitious materials needs to be established, which provides a basis for improving the application prospects of waste gypsum, and further research is needed.

(3) Research on the control mechanism of efflorescence of waste gypsum-alkali slag cement cementitious material system. There are differences in the sensitivity of waste gypsum and GBFS to different types of activators [42]. The performance of cement will also change with the change of the activator. However, with the dissolution of the waste gypsum, the $\mathrm{SO}_{4}{ }^{2-}$ ions in the liquid phase and the $\mathrm{Na}^{+}$ions in the activator form $\mathrm{Na}_{2} \mathrm{SO}_{4}$, which migrates to the cement surface with the loss of water, resulting in efflorescence, which is not conducive to the performance of cement. Therefore, the efflorescence control mechanism of waste gypsum in the application of alkali slag cement still needs to be studied in depth.

\section{Conclusions}

This article comparatively studied and explained the effect of different types of waste gypsum on the properties of alkali slag cement and pointed out that the change in the microstructure of hardened cement caused by hydration products is the main reason for the difference in performances. Through research, it not only provided new ideas for the resource utilization of waste gypsum, but also provided basis and reference value for the application of waste gypsum in alkali-activated cementitious materials. Based upon the results, following conclusions were made.

(1) Both FG and FGD gypsum significantly prolonged the initial and final setting times of cement. The initial and final setting time of cement were prolonged from 8 min and $31 \mathrm{~min}$ of the control sample to 64 and $182 \mathrm{~min}$ respectively when the content of FG is $15 \mathrm{wt} . \%$; when the content of FGD gypsum is $15 \mathrm{wt} . \%$, they were respectively prolonged to 71 and $85 \mathrm{~min}$.

(2) For the FG and FGD gypsum contents of 5 and 6 wt.\%, respectively, the compressive strengths of cements reached their maximum values. Compared with the control sample, the 28-day compressive strength increased by $24.5 \%$ and $33.9 \%$, respectively. 
(3) The incorporation of gypsum promoted the formation of ettringite crystals and other hydration products in the paste. The formation of ettringite and the difference in the properties of gypsum were the main causes of changes in the properties of cements. The amount of ettringite produced increased with the increase in the content of gypsum.

(4) The difference in the solubilities of FG and FGD gypsum led to changes in the hydration process and different cumulative heat releases. After adding gypsum, the morphology of the paste changed from only containing $\mathrm{C}(\mathrm{N})-\mathrm{A}-\mathrm{S}-\mathrm{H}$ gel to the coexistence of ettringite, gels and other products. Meanwhile, $\mathrm{Na}_{2} \mathrm{SO}_{4}$ crystallization was also observed.

(5) The formation of ettringite effectively reduced the porosity of hardened cement, optimized the pore size distribution, and improved the compactness of hardened cement.

Author Contributions: Conceptualization, C.W. and Y.W.; methodology, C.W. and Y.W.; formal analysis, C.W. and Y.W.; investigation, H.H.; data curation, H.H.; writing-original draft preparation, H.H. and W.X.; writing - review and editing, Y.W. and H.H.; supervision, Y.W.; project administration, C.W. and Y.W.; funding acquisition, C.W. All authors have read and agreed to the published version of the manuscript.

Funding: This research was funded by National Natural Science Foundation of China (No.52074101), Henan Innovative Science and Technology Team Support Project (CXTD2017088), Research Project of Science and Technology in Henan Province (no. 202102310217), the fellowship of China Postdoctoral Science Foundation (2020M682290), and the doctor foundation of Henan Polytechnic University (B2020-11).

Institutional Review Board Statement: Not applicable. Our study did not involve humans or animals.

Informed Consent Statement: Not applicable.

Data Availability Statement: Data used to support the findings of this study are available from the corresponding author upon request.

Acknowledgments: The authors appreciate the support from the school of energy science and engineering and the school of materials science and engineering in Henan Polytechnic University, PRC.

Conflicts of Interest: The authors declare no conflict of interest.

\section{References}

1. Guan, X.; Liu, S.; Feng, C.; Qiu, M. The hardening behavior of $\gamma-C_{2} S$ binder using accelerated carbonation. Constr. Build. Mater. 2016, 114, 204-207. [CrossRef]

2. Liu, S.; Dou, Z.; Zhang, S.; Zhang, H.; Guan, X.; Feng, C.; Zhang, J. Effect of sodium hydroxide on the carbonation behavior of $\beta$-dicalcium silicate. Constr. Build. Mater. 2017, 150, 591-594. [CrossRef]

3. Shi, C.; Roy, D.; Krivenko, P. Alkali-Activated Cements and Concretes; CRC Press: Boca Raton, FL, USA, 2006 ; pp. 147-150.

4. Caijun, S.; Fuqiang, H.; Fernandez-Jimenez, A.; Krivenko, V.P.; Palomo, A. Classification and characteristics of alkali-activated cements. J. Chin. Ceram. Soc. 2012, 40, 69-75. [CrossRef]

5. Escalante-Garcia, J.I.; Martínez-Aguilar, O.A.; Gomez-Zamorano, L.Y. Calcium sulphate anhydrite based composite binders; effect of Portland cement and four pozzolans on the hydration and strength. Cem. Concr. Compos. 2017, 82, 227-233. [CrossRef]

6. Singh, M.; Garg, M. Durability of cementing binders based on fly ash and other wastes. Constr. Build. Mater. 2007, 21, 2012-2016. [CrossRef]

7. Yao, Y.; Yang, D.; Zeng, J.; Sun, L.; Li, W. Influences of fly ash and fluorgypsum on the hydration heat and compressive strength of cement. J. Therm. Anal. Calorim. 2011, 106, 869-874. [CrossRef]

8. Garg, M.; Pundir, A. Investigation of properties of fluorogypsum-slag composite binders-hydration, strength and microstructure. Cem. Concr. Compos. 2014, 45, 227-233. [CrossRef]

9. Magallanes-Rivera, R.X.; Escalante-García, J.I. Hemihydrate or waste anhydrite in composite binders with blast-furnace slag: Hydration products, microstructures and dimensional stability. Constr. Build. Mater. 2014, 71, 317-326. [CrossRef]

10. Bigdeli, Y.; Barbato, M.; Gutierrez-Wing, M.T.; Lofton, C.D. Use of slurry fluorogypsum (FG) with controlled pH-adjustment in FG-based blends. Constr. Build. Mater. 2018, 163, 160-168. [CrossRef]

11. Bigdeli, Y.; Barbato, M.; Gutierrez-Wing, M.T.; Lofton, C.D.; Rusch, K.A.; Jung, J.; Jang, J. Development of new pH-adjusted fluorogypsum-cement-fly ash blends: Preliminary investigation of strength and durability properties. Constr. Build. Mater. 2018, 182, 646-656. [CrossRef] 
12. Escalante-García, J.I.; Rios-Escobar, M.; Gorokhovsky, A.; Fuentes, A.F. Fluorgypsum binders with OPC and PFA additions, strength and reactivity as a function of component proportioning and temperature. Cem. Concr. Compos. 2008, 30, 88-96. [CrossRef]

13. Huang, X.; Jiang, M.; Zhao, X.; Tang, C. Mechanical properties and hydration mechanisms of high-strength fluorogypsum-blast furnace slag-based hydraulic cementitious binder. Constr. Build. Mater. 2016, 127, 137-143. [CrossRef]

14. Wang, Y.; Yu, J.; Wang, J.; Guan, X. Effects of aluminum sulfate and quicklime/fluorgypsum ratio on the properties of calcium sulfoaluminate (CSA) cement-based double liquid grouting materials. Materials 2019, 12, 1222. [CrossRef] [PubMed]

15. Yan, Y.; Daowu, Y.; Haixia, T.; Julan, Z.; Yi, L. Modification of waste fluorgypsum and its applications as a cement retarder. J. Cent. South Univ. Technol. 2011, 18, 1402-1407. [CrossRef]

16. Garg, M.; Minocha, A.K.; Jain, N. Environment hazard mitigation of waste gypsum and chalk: Use in construction materials. Constr. Build. Mater. 2011, 25, 944-949. [CrossRef]

17. Lei, D.; Guo, L.; Sun, W.; Liu, J.; Miao, C. Study on properties of untreated FGD gypsum-based high-strength building materials. Constr. Build. Mater. 2017, 153, 765-773. [CrossRef]

18. Guo, X.; Shi, H. Influence of thermally treated flue gas desulfurization (FGD) gypsum on performance of the slag powder concrete. J. Wuhan Univ. Technol.-Mater. Sci. Ed. 2013, 28, 1122-1127. [CrossRef]

19. Caillahua, M.C.; Moura, F.J. Technical feasibility for use of FGD gypsum as an additive setting time retarder for Portland cement. J. Mater. Res. Technol. 2018, 7, 190-197. [CrossRef]

20. Li, H.; Zhang, H.; Li, L.; Ren, Q.; Yang, X.; Jiang, Z.; Zhang, Z. Utilization of low-quality desulfurized ash from semi-dry flue gas desulfurization by mixing with hemihydrate gypsum. Fuel 2019, 255, 115783. [CrossRef]

21. Wansom, S.; Chintasongkro, P.; Srijampan, W. Water resistant blended cements containing flue-gas desulfurization gypsum, Portland cement and fly ash for structural applications. Cem. Concr. Compos. 2019, 103, 134-148. [CrossRef]

22. Zhang, Y.; Pan, F.; Wu, R. Study on the performance of FGD gypsum-metakaolin-cement composite cementitious system. Constr. Build. Mater. 2016, 128, 1-11. [CrossRef]

23. Duan, S.; Liao, H.; Cheng, F.; Song, H.; Yang, H. Investigation into the synergistic effects in hydrated gelling systems containing fly ash, desulfurization gypsum and steel slag. Constr. Build. Mater. 2018, 187, 1113-1120. [CrossRef]

24. Wu, Q.; Ma, H.; Chen, Q.; Huang, Z.; Zhang, C.; Yang, T. Preparation of waterproof block by silicate clinker modified FGD gypsum. Constr. Build. Mater. 2019, 214, 318-325. [CrossRef]

25. Zhao, F.; Liu, H.; Hao, L.; Li, Q. Water resistant block from desulfurization gypsum. Constr. Build. Mater. 2012, 27, 531-533. [CrossRef]

26. Ioannou, S.; Reig, L.; Paine, K.; Quillin, K. Properties of a ternary calcium sulfoaluminate-calcium sulfate-fly ash cement. Cem. Concr. Res. 2014, 56, 75-83. [CrossRef]

27. Ren, C.; Wang, W.; Li, G. Preparation of high-performance cementitious materials from industrial solid waste. Constr. Build. Mater. 2017, 152, 39-47. [CrossRef]

28. Lee, M.; Kang, D.; Jo, H.; Park, J. Carbon dioxide utilization with carbonation using industrial waste-desulfurization gypsum and waste concrete. J. Mater. Cycles Waste Manag. 2016, 18, 407-412. [CrossRef]

29. Song, K.; Kim, W.; Bang, J.; Park, S.; Jeon, C.W. Polymorphs of pure calcium carbonate prepared by the mineral carbonation of flue gas desulfurization gypsum. Mater. Des. 2015, 83, 308-313. [CrossRef]

30. Jiang, L.; Li, C.; Wang, C.; Xu, N.; Chu, H. Utilization of flue gas desulfurization gypsum as an activation agent for high-volume slag concrete. J. Clean. Prod. 2018, 205, 589-598. [CrossRef]

31. Escalante-García, J.I.; Magallanes-Rivera, R.X.; Gorokhovsky, A. Waste gypsum-blast furnace slag cement in mortars with granulated slag and silica sand as aggregates. Constr. Build. Mater. 2009, 23, 2851-2855. [CrossRef]

32. Standardization Administration of the People's Republic of China. GB/T1346-2011: Test Methods for Water Requirement of Normal Consistency, Setting Time and Soundness of the Portland Cement; China Architecture and Building Press: Beijing, China, 2011.

33. Hewlett, P.; Liska, M. Lea's Chemistry of Cement and Concrete, 5th ed.; Elsevier Butterworth Heinemann: Amsterdam, The Netherlands, 2019; pp. 469-502.

34. Fořt, J.; Novotný, R.; Vejmelková, E.; Trník, A.; Rovnaníková, P.; Keppert, M.; Pommer, V.; Cerny, R. Characterization of geopolymers prepared using powdered brick. J. Mater. Res. Technol. 2019, 8, 6253-6261. [CrossRef]

35. Bernal, S.A.; San Nicolas, R.; Myers, R.J.; Mejía De Gutiérrez, R.; Puertas, F.; van Deventer, J.S.J.; Provis, J. MgO content of slag controls phase evolution and structural changes induced by accelerated carbonation in alkali-activated binders. Cem. Concr. Res. 2014, 57, 33-43. [CrossRef]

36. Anjos, M.A.S.; Camões, A.; Campos, P.; Azeredo, G.A.; Ferreira, R.L.S. Effect of high volume fly ash and metakaolin with and without hydrated lime on the properties of self-compacting concrete. J. Build. Eng. 2020, 27, 100985. [CrossRef]

37. Wang, Y.; Luo, S.; Yang, L.; Ding, Y. Microwave curing cement-fly ash blended paste. Constr. Build. Mater. 2021, $282,122685$. [CrossRef]

38. Li, Y.; Li, J. Capillary tension theory for prediction of early autogenous shrinkage of self-consolidating concrete. Constr. Build. Mater. 2014, 53, 511-516. [CrossRef]

39. Son, H.; Park, S.M.; Seo, J.H.; Lee, H.K. Effect of $\mathrm{CaSO}_{4}$ incorporation on pore structure and drying shrinkage of alkali-activated binders. Materials 2019, 12, 1673. [CrossRef] [PubMed] 
40. Wang, D.; Wang, Q.; Huang, Z. New insights into the early reaction of $\mathrm{NaOH}$-activated slag in the presence of $\mathrm{CaSO}_{4}$. Compos. Part B Eng. 2020, 198, 108207. [CrossRef]

41. Garg, M.; Pundir, A. Energy efficient cement free binder developed from industry waste-A sustainable approach. Eur. J. Environ. Civ. Eng. 2017, 21, 612-628. [CrossRef]

42. Yoon, S.; Park, H.; Yum, W.; Suh, J.; Oh, J. Influence of calcium sulfate type on evolution of reaction products and strength in $\mathrm{NaOH}-$ and $\mathrm{CaO}-$ activated ground granulated blast-furnace slag. Appl. Sci. 2018, 8, 2500. [CrossRef] 